\title{
Influence of Pollen on Solar Photovoltaic Energy: Literature Review and Experimental Testing with Pollen
}

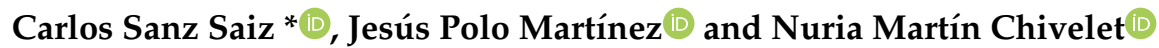 \\ Research Centre for Energy, Environment and Technology (CIEMAT), Avda. Complutense 40, \\ 28040 Madrid, Spain; jesus.polo@ciemat.es (J.P.M.); nuria.martin@ciemat.es (N.M.C.) \\ * Correspondence: carlos.sanz@ciemat.es; Tel.: +34-914-962-513
}

Received: 25 June 2020; Accepted: 7 July 2020; Published: 9 July 2020

check for updates

\begin{abstract}
This work attempts to shed some light on the impact of organic soiling due to pollen on solar photovoltaic (PV) power generation. Apart from introducing several soiling-related pollen features, the previous works reporting soiling by pollen have been reviewed. Local observations from late winter to early spring showed that a rooftop PV system experienced both uniform and non-uniform soiling issues, which were mainly caused by pollen from nearby cypress specimens. In addition, this work publishes preliminary results regarding an artificial soiling test performed with pollen. In this test, soda lime float glass coupons were artificially soiled with fresh cypress pollen. A linear relationship was found between the pollen mass density $\left(\rho_{A}\right)$ and the glass averaged transmittance $\left(T_{\mathrm{AVE}}\right)$ for values up to $9.1 \mathrm{~g} / \mathrm{m}^{2}$. In comparison with other artificial soiling tests performed with different soiling agents, the transmittance loss caused by pollen cypress deposition was relatively high and spectrally selective.
\end{abstract}

Keywords: photovoltaic performance; organic soiling; biological soiling; pollen; transmittance loss; artificial soiling test

\section{Introduction}

According to the increasing number of scientific and technical papers published in recent times [1], the analysis of the soiling loss (i.e., the energy production loss caused by soiling) in photovoltaic (PV) systems has become an important topic of interest within the solar energy community. In particular, there are many works dealing with soiling by mineral dust in arid world regions with abundant solar resource [2,3]. Soiling (i.e., dirt accumulation) is a very complex issue due to the large number of influencing parameters: the geographical location, the PV plant design, the PV module type, the surrounding environment, the specific particles causing soiling, and their seasonal atmospheric loads, etc. All these factors determine the local severity of soiling as well as the maintenance operations required to deal with it [4].

Owing to the outdoor operating conditions, the front glass cover of the PV modules will gradually accumulate dirt at a variable rate [5]. As a result, the built-up soiling layer reduces the glass transmittance by partially absorbing and reflecting the incident sunlight and, consequently, it decreases the PV energy output leading to a soiling loss [5]. Depending upon the location of the PV system, the soiling layer may consist on a variable mixture of organic and inorganic matter (e.g., soot, dust, sand, sea salt, bird droppings, leaves, pollen, etc.) coming from a variety of sources (e.g., air pollution, mineral dust aerosol, marine aerosol, microbiological colonization, etc.). Although several works have analyzed soiling in detail from different perspectives (e.g., efficiency loss, regional and climate dependence, physicochemical mechanisms, involved pollutants, 
monitoring methods, mitigation strategies, etc.) [5-9], little attention has been paid to the role of pollen. However, pollen deposition may seasonally become a concern for many PV installations (whether ground-mounted, roof-mounted, or building-integrated systems), potentially causing a significant increase on the local soiling loss.

Primary biological aerosols represent a significant fraction of the total atmospheric aerosol load. They arise when some biological processes, being exposed to air movements, generate airborne organisms or propagules. Roughly speaking, these biogenic airborne particles have diameters of less than $0.3 \mu \mathrm{m}$ for viruses, $0.25-8 \mu \mathrm{m}$ for bacteria, $1-30 \mu \mathrm{m}$ for fungal spores, $6-30 \mu \mathrm{m}$ for moss spores, $20-60 \mu \mathrm{m}$ for fern spores, $17-58 \mu \mathrm{m}$ for anemophilous pollen, etc. [10,11]. Hence, as pollen aerosols are composed by rather large particles, the "pollen blooms" causing soiling would not be properly detected through the atmospheric parameters PM2.5 and PM10, requiring alternative monitoring approaches instead, such as consulting aerosol optical depth (AOD) measurements $[12,13]$ or, even better, consulting real-time local data from aerobiological monitoring stations [14].

The airborne pollen spectrum depends on several factors which influence the production, the release, and the dispersion of pollen. Basically, these factors are related to the geographical location, the vegetation in the area of influence, the time of the year and the weather conditions [15]. In more detail, some important factors are the height of pollen release, the pollen grain aerodynamics (e.g., size, shape, density, surface roughness), the phenology of the local vegetation (i.e., its annual blossoming period) and the local meteorology (e.g., solar radiation, temperature, relative humidity, precipitation, wind direction, wind velocity, air turbulence) $[10,15,16]$. Concerning Europe, recent decades have witnessed a general trend towards rising airborne pollen concentrations; such phenomenon becomes more pronounced in urban areas next to parks, gardens, avenues, etc., being mainly caused by the abundance of tree pollen [17]. With regard to the Iberian Peninsula, the contribution of ornamental trees (Platanus sp., Cupressaceae, Fraxinus sp.) in urban areas, wild trees (Quercus sp., Fraxinus sp.) in forestry-linked areas, and extensive olive crops (Olea europaea) in the southern region has been emphasized [18].

The spatial-temporal scale of the aerial transport of pollen is difficult to ascertain. Rantio-Lehtimäki [19] differentiated between short-range transport (i.e., pollen produced at local level which lasts no more than 1 hour in the air and reaches from $100 \mathrm{~m}$ to $1 \mathrm{~km}$ ); medium-range transport (i.e., pollen produced at regional level which lasts about 1 day in the air and reaches from 1 to $100 \mathrm{~km}$ ) and long-range transport (i.e., pollen produced in remote regions which remains in the air during several days and can travel even continental or intercontinental distances). In any case, as the pollen grains are coarse airborne particles, gravitational settling becomes their major deposition mode [20], which usually limits their atmospheric lifetime to a few hours [21]. As a consequence, from a quantitative point of view, pollen deposition only becomes relevant over the first kilometer(s) from the source $[15,22]$.

Pollen grains are the male reproductive cells of the seed-bearing plants, which include both Gymnosperms (e.g., pine, fir, cedar, cypress, etc.) and Angiosperms (e.g., plane tree, olive, oak, birch, etc.). The pollen grain protects the inner cytoplasm with an external wall ("sporoderm") which usually combines a pectocellulose-rich inner layer ("intine") and a complex sporopollenin-rich outer layer ("exine"), although the latter may be reduced or even absent in some vegetal species $[23,24]$. Besides, the outermost part of the exine, which is sometimes referred to as "sexine", displays a submicronic sculpturing pattern ("ornamentation") which varies depending on the vegetal species: smooth, reticulate (grooved), echinate (spiked), etc. [11,25].

After mature pollen grains are released by the floral organ, their aerial transport and deposition may include a series of processes: wind dispersion, several dry/wet deposition mechanisms (e.g., sedimentation, turbulent deposition, impaction, rain scavenging, etc.), and resuspension of dry deposited pollen. Meanwhile, apart from interacting with moisture, wind, and UV radiation, airborne pollen is affected by atmospheric pollution [26]. Pollen can adsorb suspended particulate matter, either inorganic or organic, but mostly belonging to the PM2.5 fraction [27]. With that said, 
the most common alteration experienced by pollen is the harmomegathic effect: pollen grains undergo minor volume and/or shape changes due to cytoplasmic water uptake/loss before, during and after pollen dispersal. Concerning the aerial transport stage, such changes happen depending on the air humidity, as the water content of the pollen grains fluctuates towards equilibrium [16,23].

A good number of knowledge areas (e.g., botany, ecology, allergology, atmospheric sciences, etc.) have provided extensive but disperse information about pollen. Here, rather than presenting a global review of the science of pollen, a reference framework for the research on soiling by pollen will be presented. Hence, some particularities of pollen will be introduced because of their implications for soiling in Section 2. Next, the literature published so far reporting PV-related soiling issues caused by pollen will be summarized in Section 3. Moreover, the influence of soiling on PV energy will be introduced in Section 3, where both a review of the reported soiling issues due to pollen and an experimental assessment of PV soiling losses are presented. Then, a preliminary artificial soiling test performed with pollen is described in Section 4. The test, which has been carried out using fresh cypress pollen as soiling agent, has provided an empirical correlation between the mass density of the deposited pollen $\left(\rho_{\mathrm{A}}\right)$ and the remaining optical transmittance of the glass substrate $\left(T_{\mathrm{AVE}}\right)$. This relationship could help to interpret the soiling loss on PV sites undergoing significant pollen deposition. Finally, the main conclusions of this work are summarized in Section 5.

It should be noted that the names of the botanical families and genera are written in regular letters and italics, respectively. Moreover, references to the climate conditions follow the Köppen-Geiger climate classification [28].

\section{Soiling-Related Pollen Topics}

Among others, this section will remark the following facts:

- Pollen blooms are seasonal events, typically occurring during springtime.

- The beginning, intensity, and duration of the main pollen season, in which most pollen blooms happen, vary from year to year.

- The airborne pollen levels depend on the local vegetation, the local meteorology, and the time of the year.

- Soiling by pollen is a local-scale phenomenon.

- The soiling potential of pollen differs among the vegetal families, genres, and species.

- Anemophilous species, and particularly anemophilous trees, are prone to cause soiling by pollen.

- Local soiling by pollen could be predicted and/or estimated.

\subsection{Pollination Strategies}

Once pollen grains have matured within the male reproductive organs of the plant, they must reach the conspecific female counterparts in order to manage pollination. Depending on the vegetal species, this may happen either via self-pollination (i.e., the flower fertilizes itself) or, more frequently, via cross-pollination, in which case the pollen grains are transported by at least one external agent ("pollination vector") [29]. A pollination vector can be either abiotic (i.e., wind, rarely water) or biotic (i.e., animals, mostly insects), but more interestingly, a distinct soiling potential should be expected from plants with different pollination strategies. As explained in the following paragraph, the pollination strategy is closely related to the pollen production level, the atmospheric pollen concentration, and the pollen grain properties.

Almost all the Gymnosperm families and some of the Angiosperm families ( 18\%) are anemophilous (i.e., wind-pollinated plants) [29]. Typically, anemophilous species produce large amounts of pollen, which has been sometimes interpreted as a compensation for having a lower pollination efficiency than entomophilous species (i.e., insect-pollinated plants) [30]. Moreover, while most anemophilous species release non-aggregated pollen (i.e., smaller, smoother, lighter, and non-sticky particles whose aerodynamics favor wind transport), entomophilous species release 
aggregated pollen (i.e., larger, coarser clumps of sticky pollen grains which favor insect transport) [29,31]. Therefore, the pollen produced by strictly anemophilous plants and, to a lesser extent, by ambophilous plants (i.e., vegetal species pollinated by both wind and insects) are notably present in the atmosphere [32]. As confirmed by data from aerobiological monitoring stations, they become relevant contributors to the total airborne pollen concentration and thus to the organic soiling issues underwent by PV modules under the area of influence. In comparison, clumped pollen from strictly entomophilous species would modestly contribute to the total airborne pollen spectrum and, consequently, it might only pose a soiling risk in case of abundant dropping from vegetation placed almost over the PV modules.

\subsection{Pollen Particle Size}

Pollen grains exhibit a large interspecific variability concerning their morphological features: size, shape, polarity, apertures, pollen wall structure, ornamentation, coating, etc. [25]. For our purpose, which is considering pollen as a soiling agent, the pollen particle size is the primary morphological characteristic, although more factors will affect the area susceptible to soiling by pollen (by influencing the pollen dispersion, transport, and deposition) and the properties of the resulting soiling layer. These factors, which will be addressed later, are pollen aggregation and disaggregation, pollen fragmentation, pollen hygroscopicity and pollen surface chemistry.

The pollen particle size depends on the vegetal families, genres, and species. The first consideration is that the individual pollen grains cover a broad size interval. As the pollen grain size fluctuates because of its natural variation, its degree of hydration and its preparation method, it is recommended to categorize it by "size classes" according to the length of its longest axis [33]. Erdtman (1969) [25] stablished the following size classes for sporomorphs (i.e., pollen and spores): very small $(<10 \mu \mathrm{m})$, small $(10-24 \mu \mathrm{m})$, medium $(25-49 \mu \mathrm{m})$, large (50-99 $\mu \mathrm{m})$, very large $(100-200 \mu \mathrm{m})$, and gigantic $(>200 \mu \mathrm{m})$. A more recent criteria classifies the pollen size as very small $(<10 \mu \mathrm{m})$, small $(10-25 \mu \mathrm{m})$, medium $(26-50 \mu \mathrm{m})$, large $(51-100 \mu \mathrm{m})$, and very large $(>100 \mu \mathrm{m})[33,34]$. Airborne pollen grains are mainly small- or medium-sized, although some of them have large or very large sizes (Figure 1). These exceptions usually correspond to "saccate pollen" (i.e., pollen grains having one to three air-filled bladders), which is exclusive of three conifer families (i.e., Pinaceae, Podocarpaceae, and Phyllocladaceae) including several conifer genera (e.g., Pinus, Cedrus, Picea, Abies, etc.). Such pollen grains can manage wind dispersal because their morphological adaptation compensates for a larger particle size through enhanced aerodynamics [35,36].

The second consideration is that not all the vegetal species disperse pollen grains individually. There exists a variety of pollen dispersal units (PDUs) ranging from solitary pollen grains ("monads") to massive pollen clumps ("pollinariums"), which affects the pollen particle size, shape, mass ... Sometimes several pollen grains have common walls: dyads (two grains), pseudomonads (three grains), tetrads (four grains), and multiples of tetrads such as polyads (up to 32 grains), massulae and pollinium. In addition, monads, tetrads and other pollen units may further group together through exines coated by viscous fluids (e.g., pollenkitt, primexine matrix, tryphine, elastoviscine) or exines with entangling filaments (i.e., viscin threads) [24,39]. That said, anemophilous plants, whether Gymnosperms or Angiosperms, are known to disperse solitary monads (e.g., Betulaceae, Urticaceae, Poaceae, etc.) with few exceptions (for instance, Cistaceae and Myrtaceae disperse monads clumped by pollenkitt) [40]. In contrast, most entomophilous plants produce pollen clumps and some of them disperse a range of PDUs [39].

A rough idea of the relative abundance of the pollen size classes and the PDU classes can be inferred from Figure 2. Among the included vegetal species, the two main PDUs are monads $(92.2 \%)$ and tetrads (3.4\%). In addition, some Angiosperm families have been classified according to their representative PDU classes [41]. 


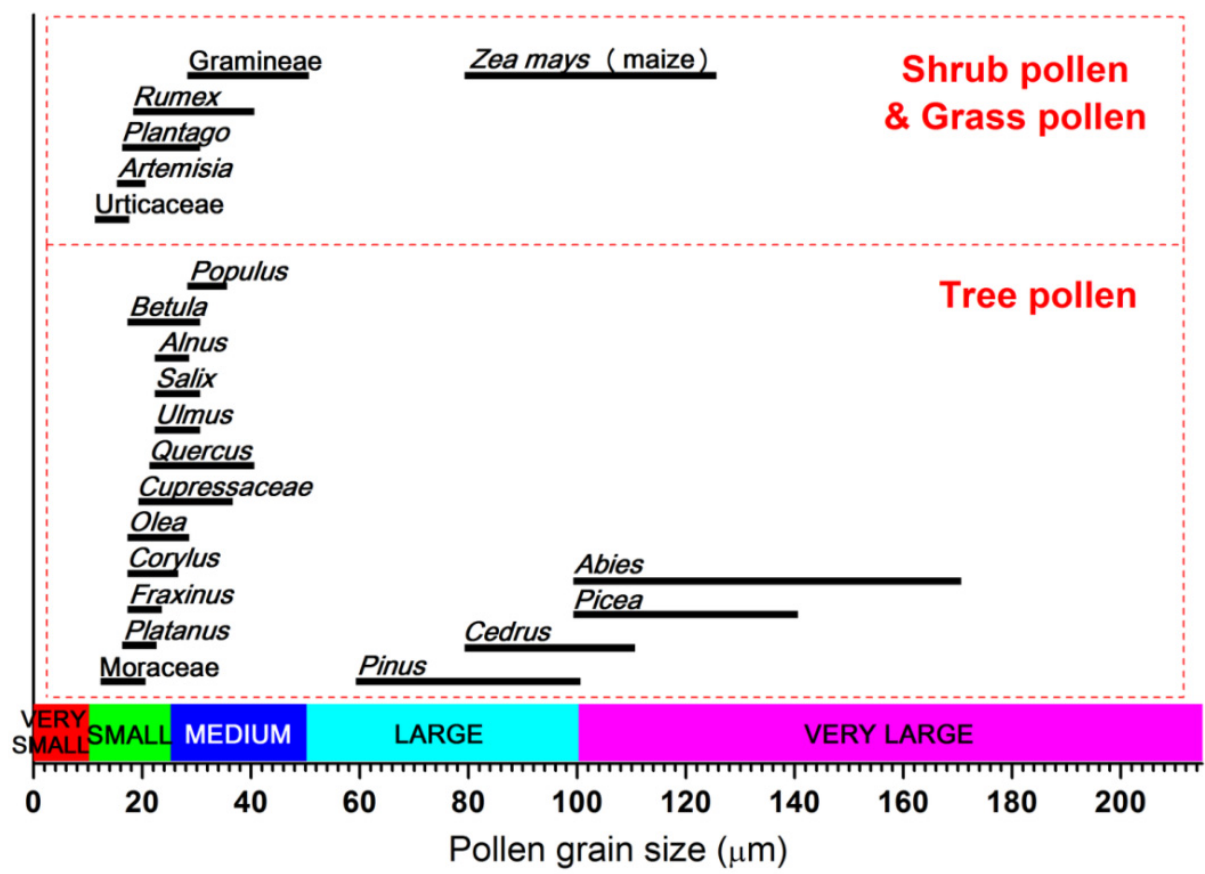

Figure 1. Single-grain size distribution of pollen of common Mediterranean plants (data gathered from $[11,37,38])$. The colored bottom bar and the black horizontal lines represent the grain size classes and the grain size spans of the vegetal families, genres or species, respectively.

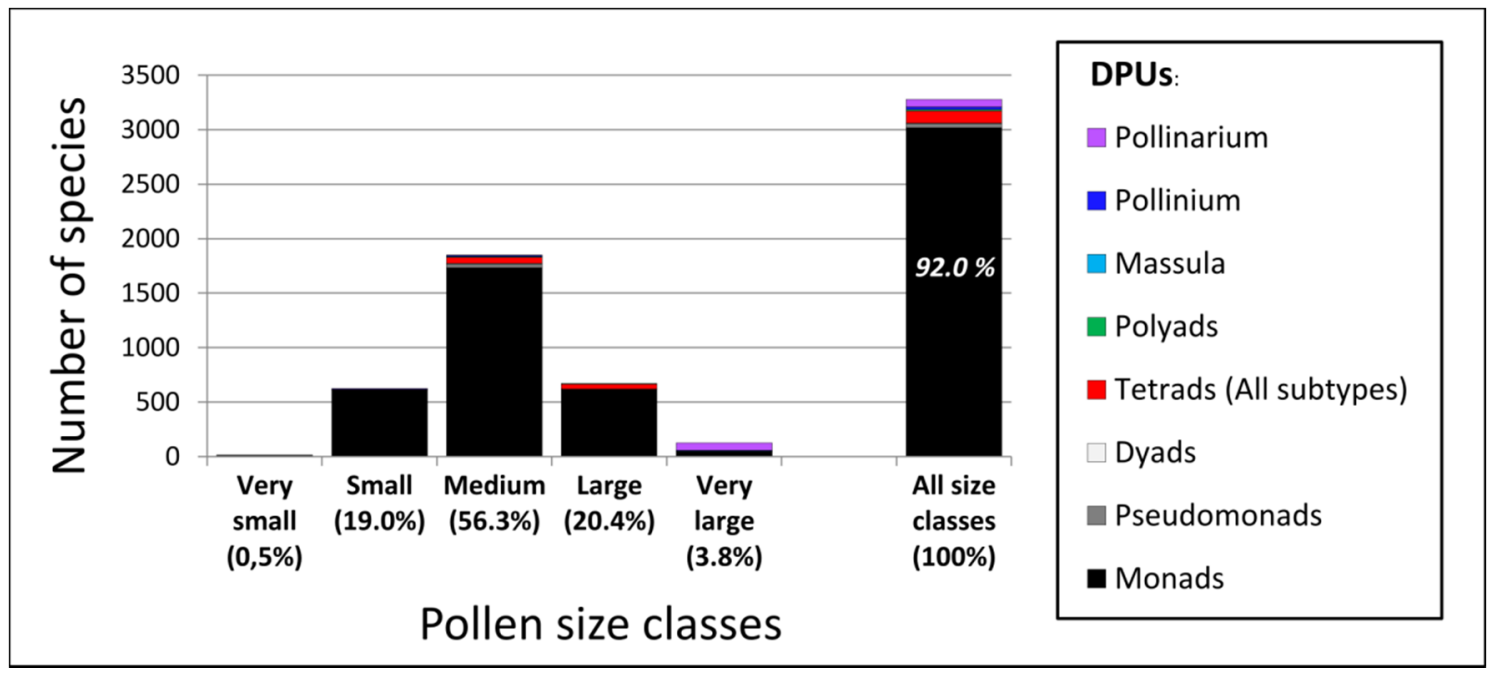

Figure 2. Distribution of the vegetal species per pollen size class (columns) and per pollen dispersal unit (colored bars). This graph is for indicative purposes: the data sampling was limited to the 3280 vegetal species included in the palynological database PalDat (last accessed: 12 June 2020) [34].

\subsection{Pollen Aggregation and Disaggregation}

As already mentioned, some types of vegetation disperse aggregated pollen grains ("pollen clumps") instead of solitary pollen grains. For example, holm oaks and oaks (Quercus sp.), willows (Salix sp.) and elms (Ulmus sp.) are atypical anemophilous trees because they disperse pollen clumps [10]. Furthermore, pollen disaggregation is sometimes possible: during their aerial dispersion, larger pollen clumps may fragment into smaller ones due to the exposure to turbulent wind [42]. In any case, the formation of larger airborne particles will influence the soiling potential of pollen by affecting its aerial transport, its deposition processes, its adhesion forces, etc. 
In most cases, pollen aggregation takes place thanks to some viscous fluid which holds the pollen grains together: pollenkitt (which is the most common one and resides over the exine and/or within the exine cavities), tryphine (only in Brassicaceae), elastoviscine (in Orchidaceae and Asclepiadaceae) ... [43]. In general, pollenkitt is abundant in entomophilous pollen (e.g., $60 \%$ and $30 \%$ mass content in dandelion and sunflower, respectively), it is present to a lesser extent in ambophilous pollen (e.g., $8 \%$ mass content in olive) and it is essentially missing in anemophilous pollen (e.g., still 10\% mass content in poplar; absent among almost all Gymnosperms) [43-45]. Finally, pollen aggregation is also influenced by other factors, such as the relative humidity or the time elapsed since the anther dehiscence [39].

\subsection{Pollen Fragmentation}

Whole pollen grains may experience both osmotic and mechanical rupture. On the one side, airborne pollen grains can swell up through moisture absorption to the point of rupturing osmotically during rainy or stormy weather, releasing numerous smaller particles which increase the parameters PM2.5 and PM10 [46,47]. On the other side, pollen grains can undergo mechanical rupture due to impaction against outdoor surfaces at relevant wind speeds, as observed on birch pollen releasing near-submicronic particles [48].

\subsection{Pollen Hygroscopicity}

Hygroscopicity largely impacts the transport and deposition of pollen, as airborne pollen grains tend to inflate and fall down by absorbing water under high relative humidity conditions. Pollen from several anemophilous and entomophilous plants have shown substantial mass increases due to water uptake $[49,50]$. Angiosperm pollen grains are moderately hygroscopic and wettable under subsaturated conditions [32,51]. For instance, birch and walnut pollen grains exhibited a mild volume gain when exposed to an increasing relative humidity $(\mathrm{RH})$, with $68 \%-93 \% \mathrm{RH}$ causing internal swelling and $\mathrm{RH}>95 \%$ causing additionally a surface water uptake [32]. Regarding Gymnosperm pollen, taxoid-type pollen (e.g., Cupressaceae, Taxaceae, and Taxodiaceae) undergo an osmotic shock in aqueous media, which occurs via hydration, intine swelling and exine rupture/release [52]. For instance, Cupressus arizonica pollen grains became fragmented after remaining dipped in water for 24-48 h [53].

With respect to the soiling process, it could be boosted by the coincidence of condensed moisture with high air pollen levels: the pollen grains could get readily trapped by the wet PV module surfaces due to the water surface tension, as suggested during night dew events [54].

\subsection{Pollen Surface Chemistry}

Determining the pollen chemistry requires complex and time-consuming analytical methods, but vibrational spectroscopies coupled with multivariate data analysis have recently shown great potential for rapid chemical characterization, identification, and classification of pollen. These techniques have confirmed that pollen has relatively uniform and specific chemical compositions within the different plant families [55].

Regarding the pollen surface chemistry, a wettability test performed with pollen of 15 vegetal species found that the pollen from 11 species was strongly hydrophilic and the pollen from the remaining four species was weakly hydrophilic. Regretfully, that investigation did not include pollen chemical analyses to correlate the observed behaviors with the chemical composition [56]. As already mentioned, the outer layer of the external wall of the pollen grains ("exine") is mainly composed of sporopellin, which is a biopolymer of variable and largely unknown composition and structure, and may be partially or totally covered by viscous fluids. Among them, while tryphine is a mixture of hydrophilic and hydrophobic substances, pollenkitt is hydrophobic because it is mainly composed by lipids [43]. Hence, it would be plausible that some pollenkitt-rich pollen grains might exhibit a hydrophobic behavior. In addition, the presence of pollenkitt promotes both pollen aggregation (Section 2.3) and pollen adhesion (Section 2.7). 


\subsection{Pollen Adhesion Forces}

This subsection will address the adhesion of pollen to inert flat surfaces. Its net adhesion force may have three contributors: van der Waals forces, capillary forces, and electrostatic forces. Adhesion experiments performed with several pollen types and flat surfaces showed that the adhesion strength of the pollen grains had a heavy reliance on both the presence or absence of pollenkitt (i.e., a sticky covering substance) and the exine ornamentation (i.e., the external surface morphology). For pollen grains without pollenkitt, the adhesion force primarily consisted in van der Waals forces and was independent of the surface. In contrast, for pollen grains with pollenkitt, both capillary bridges and van der Waals forces were significant; the pollenkitt-related contribution to adhesion was highly species-dependent and the net adhesion force was dependent on the surface hydrophilicity. Besides, the adhesion strength increased along with the effective contact area between the pollen grain and the flat surface [44]. In other words: in the absence of significant electrostatic forces, the pollen adhesion is basically governed by a dry mechanism controlled by the van der Waals forces (as a function of the grain size, the grain shape and the "surface density" of the exine ornamentation) and, provided that such pollen contains pollenkitt, also by a wet mechanism controlled by the capillary forces due to the pollenkitt liquid bridges formed between the pollen grain surface and the flat surface [44]. In any case, the resulting pollen adhesion strength is humidity-dependent: while the adhesion force to a hydrophilic surface was found to increase with the relative humidity (RH) up to $70 \% \mathrm{RH}$ for pollen with and without pollenkitt, the adhesion to a hydrophobic surface was independent of the RH for pollenkitt-free pollen but exhibited a complex dependence on the RH for pollen with pollenkitt [57]. Moreover, the pollenkitt adhesive strength may vary according to its freshness and to the RH: on hydrophilic surfaces (i.e., uncoated glass) a higher RH increased pollen adhesion regardless of the pollen condition (i.e., fresh, aged, without pollenkitt), but on hydrophobic surfaces (i.e., silanized glass) the adherence was significantly lower for fresh pollen than for aged pollen while the ambient humidity had little effect on the pollen adhesion [58].

In addition, pollen grains are also sensible to electrostatic forces. There is evidence of electrostatically-assisted pollen harvesting by honeybees [59]. Electrostatically-assisted artificial pollination can improve some agricultural productivities [60]. Electrostatic barrier-forming windows have managed to capture airborne pollen in order to provide pollen-free indoor air [61]. Interestingly, recent experiments have confirmed that pollen grains have a small amount of electrostatic charge (either positive or negative, with an average magnitude of $0.8 \mathrm{fC}$ ). Once released, pollen grains subjected to wind transport would retain a substantial part of their charge during several minutes before reaching electrostatic equilibrium with the air [62]. Moreover, concerning the aerial transport of pollen, electrostatics could influence it aerodynamically, namely by favoring either the separation or the clumping of the pollen grains [63].

\subsection{Pollen Dispersal Curves}

Some general research on pollen has paid attention to another soiling-related topic: the pollen dispersal curves, which describe the frequency distribution of pollen dispersal distances. In other words, they indicate how the amount of pollen deposited at ground level varies as a function of the distance from the pollen source. A dispersal curve may differ in shape depending on the height of pollen release, the pollen settling velocity, the wind speed, the wind turbulence, the morphological adaptations of pollen for aerial dispersal ... [64]. Pollen dispersal can be analyzed through Gaussian plume models $[64,65]$. According to the Gaussian tilted plume model, which calculates aerial particle dispersion considering diffusion, advection and gravitational settling, the pollen dispersal curve of an isolated tree or plant falls off with distance, but may achieve a peak at some distance away from the pollen source (Figure 3) [64]. However, in practice, many pollen dispersal curves simply fall off with distance following either an inverse power or a log-linear function. For instance, several tree species were found to follow an exponential function, causing an intense pollen deposition beneath the canopy which decreased gradually and became negligible far beyond the first tens or hundreds of 
meters. In addition, their pollen dispersal curves were shorter and less intense for punctual pollen sources than for distributed ones [66,67]. In addition, pollen deposition from maize crops was found to decrease following a power function which reached a few kilometers [38].

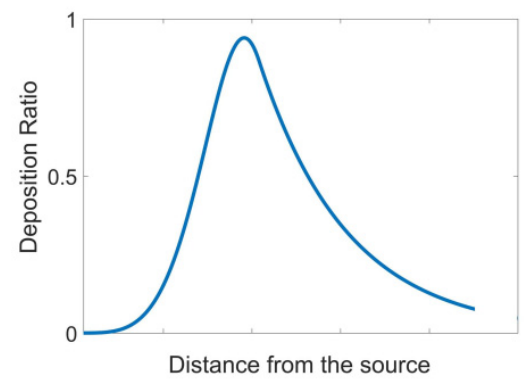

(a)

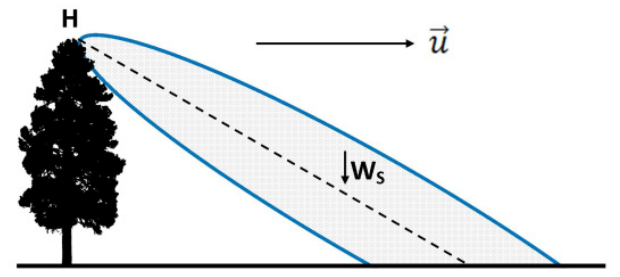

(b)

Figure 3. Gaussian tilted plume model: (a) cross-wind integrated pollen deposition at the ground; (b) schematic of pollen deposition at the ground. The parameters are: distance from the pollen source, height of pollen release $(H)$, pollen settling velocity $(W s)$, and wind mean speed $\vec{u})$. Adapted from [64].

\subsection{Airborne Pollen Monitoring}

For a given location, the "main pollen season" refers to the period with significant air pollen concentrations when considering either the pollen from a specific "pollen type" or the pollen from the whole set of pollen types [68-70]. Concerning the aerobiological parameters, the annual pollen integral (APIn) and the seasonal pollen integral (SPIn), formerly termed annual pollen index (API) and seasonal pollen index (SPI), respectively, account for the sum of the average daily pollen concentrations over the whole year and over a given period of time, respectively [70]. That is, these parameters denote the relative importance of the different pollen types in relation to the airborne total pollen concentration on a yearly or a seasonal basis $[17,18]$. Nowadays, most aerobiological monitoring networks perform pollen sampling by means of Burkard seven-day-recording volumetric traps installed at a certain height above the ground [14]. After automatic sampling, pollen grains are identified and counted by the visual inspection of optical microscope images by an experienced human operator. As the airborne pollen concentrations are not constant through the day (i.e., typically peaking at times of maximum sunlight and temperature) [71], they are reported as "mean daily values", their units being the number of pollen grains per cubic meter of air $\left(\right.$ grain $\left./ \mathrm{m}^{3}\right)$ [72]. Although the information about the airborne pollen concentrations is not readily available [14], a live worldwide map of the pollen monitoring stations has been recently published [73].

Aerobiological studies classify the airborne pollen according to a "pollen type" criteria. Through statistical data analysis, they can provide local pollen calendars which show the expected time span for the presence in air of every pollen type. Each pollen type quantifies together the pollen from all the vegetal species whose pollen grains share a distinctive external morphology under light microscopy. Hence, these pollen types may include one species, a genus (i.e., a group of species), a family (i.e., a group of genera) or wider taxonomic groups [18]. For instance, the pollen type "Cupressaceae" includes pollen from the whole Cupressaceae family, which share an "spheroidal, intectate, monoporate, and with a distinct annulus" appearance [74].

The Cupressaceae family, which is composed of numerous genera and species concentrated in the temperate world regions, consists of evergreen trees and shrubs which produce abundant anemophilous pollen [75]. The most relevant bioclimatic factor regarding their airborne pollen concentration seems to be the temperature, followed by the relative humidity [76]. In the Mediterranean region, this pollen type reaches record airborne levels during winter or early spring, although the pollen production varies largely from year to year. Concerning Spain, and focusing on the widespread cypresses (i.e., the genus Cupressus), blossoming occurs in October-November for C. macrocarpa and January-April 
for C. arizonica, C. sempervirens, and C. lusitanica [77]. Within the genus Cupressus, pollen grains are 29-38 $\mu \mathrm{m}$ in diameter [78].

\section{The Influence of Soiling on Photovoltaic Energy}

\subsection{Soiling by Pollen on PV Modules: A Review}

Pollen must be considered as a seasonal, local-scale soiling agent. At certain times of the year, airborne pollen deposition may leave a yellowish blanket over the ground and the outdoor surfaces. Certainly, pollen can build up on PV modules, particularly near the lower edge of the framed modules, affecting the energy conversion process [79]. Pollen typically causes soiling issues in springtime, which is the main blossoming season in most temperate world regions. That is to say, soiling by pollen is a consequence of reaching record-peak levels in the air pollen concentration ("pollen blooms"), which mostly occurs during spring, although it can also happen during summer or autumn $[7,12,54,80]$. Since the production and emission of pollen are governed by interacting environmental factors subjected to fluctuations, the onset, duration and intensity of the period when pollen is significantly present in the air varies from year to year [68]. Further, recent climatic change trends point towards an increasing soiling potential for pollen: in the case of Europe, the airborne pollen concentrations seem to increase and, compared to 50 years ago, the main pollen season currently starts earlier and lasts longer $[17,69]$.

Particularly, pollen becomes a concern for PV systems installed in geographical areas where high airborne pollen concentrations are periodically reached, such as in the Eastern United States [81,82]. Regarding Portugal, not only the Saharan dust events but also the pollen blooms were identified as atmospheric intrusions significantly impacting the PV performance [12]. Soiling mostly due to pollen and causing a power reduction of $4.1 \%$ was reported during a rainless spring period in southern Portugal (Csa climate) [54]. Pollen is usually mentioned among the soiling agents, particularly in agricultural areas $[6,83-85]$. Some authors have managed to identify the pollen grains of the soiling layers $[12,80,86-88]$. The determination of the pollen type (and, consequently, also of the pollen source) can be achieved based on the morphological features of the pollen grains through microscopy imaging techniques $[7,12,54]$. In this regard, reference information can be found in palynological databases such as PalDat [34,89], which is the world's largest one and a free-access online resource.

In general terms, soiling losses are reversible: most soiling layers can be removed either by rainfall or by cleaning the PV modules $[80,83,86]$. Concerning rainfall, there is not a well-defined precipitation threshold which guarantees a full restoration of the efficiency of the PV module. For instance, in the Southwestern United States, while Mejía et al. [83] reported that $2.5 \mathrm{~mm}$ would be enough, Kimber et al. [90] suggested the need for more rainfall, being roughly delimited between $5 \mathrm{~mm}$ and $20 \mathrm{~mm}$. In addition, it must not be forgotten that stubborn dirt (e.g., bird droppings, exhaust fumes ... ) can resist heavy rainfall, namely requiring scrubbing, detergents, etc. [91]. In the particular case of soiling by pollen, rainfall has been reported to effectively clean the PV modules, although the registered precipitation was not mentioned [7,54]. In any case, provided that pollen deposition may cause a significant soiling loss under prolonged rainless conditions, the maintenance regimen of the affected PV systems should include, at least, a cleaning operation of the PV modules after the end of the main pollen season [92].

In addition, an outdoor soiling test was performed in Belgium ( $\mathrm{Cfb}$ climate) during springtime by placing a series of glass coupons, both sheltered and unsheltered from rain, and by measuring the evolution of their transmittances over time [7]. Concurring with high airborne pollen levels, a significant transmittance loss happened in the sheltered glasses, where large-sized pollen grains ( $\sim 60 \mu \mathrm{m}$ in size) could be observed by scanning electron microscope. Contrarily, neither such transmittance loss nor such pollen grains were observed in the unsheltered glasses, obviously due to the cleaning effect of the rainfall. Simultaneously, a layer of smaller dust particles $(2-10 \mu \mathrm{m}$ in size) remained on both sheltered and unsheltered glasses, meaning that the rainfall had little effect on 
removing such small particles. This observation leaves the question of whether the rainfall would manage to effectively remove pollen grains having about $10 \mu \mathrm{m}$ in size.

When coping with soiling, some passive cleaning strategies could be attempted. There is evidence of both organic degradation and adherence reduction of the pollen deposited on a photocatalytic surface [93], which suggests that $\mathrm{PV}$ modules having a $\mathrm{TiO}_{2}$-based nanocoated solar glass might have some advantage in areas exposed to high airborne pollen levels. In addition, some tests performed with electrodynamic screens (EDS) showed a lower removal efficiency of pollen with respect to dust [94].

Concerning the impact of a given soiling agent (broadly referred to as "dust"), an empirical relationship between the amount of deposited dust ("dust density") and the light transmission loss [7,95-97] or the PV performance reduction $[7,98,99]$ could be established. Such experimental correlations are not suitable for universal application, as they differ depending on the nature and size of the soiling particles $[7,99]$. This implies that a given dust density will unlikely have an identical soiling impact neither when comparing different pollutants having the same particle size, nor when comparing the same pollutant with different particle sizes. Either way, for a given pollutant, smaller particles are certainly known to have a more detrimental effect on both the light transmission and the PV performance than bigger ones [98]. Unfortunately, experimental correlations for the specific case of pollen acting as the soiling agent have not been previously published.

\subsection{Experimental Assessment of PV Soiling Losses}

The "Short-term forecasting of PV energy output including the soiling effect (PVCastSOIL)" project includes the objective of monitoring and modeling soiling under Mediterranean climate conditions. To achieve this, an off-grid PV system was installed on a 10m-high rooftop at the Research Centre for Energy, Environment and Technology (CIEMAT), Madrid, Spain (Csa climate). Located within a semi-urban area, CIEMAT's facilities are surrounded by a gardened university campus, a forest park, and some paved roads. The PV system is installed above a building surrounded by well-developed conifers: cedars, cypresses, and pines (Figure 4). This PV system consists of twelve commercial PV modules (i.e., six 60-cell crystalline silicon modules and six cadmium telluride modules with peak powers of $365 \mathrm{~W}$ and $80 \mathrm{~W}$, respectively) with their corresponding temperature sensors, a PVPM2540C (PVE Photovoltaik Engineering) I-V curve tracer connected to a multiplexer, a DustIQ (Kipp \& Zonen, Delft, The Netherlands) soiling monitoring sensor, and some additional apparatus to monitor the meteorological variables (e.g., solar irradiance, temperature, wind speed, precipitation, relative humidity); a series of coated and uncoated float glass samples are exposed alongside as well. The design of this PV system will allow us to determine the local soiling ratio and the influence of the local meteorology, as well as the dependence of soiling on several technical parameters such as the PV technology (i.e., crystalline silicon versus cadmium telluride), the module inclination (i.e., $35^{\circ}$ versus $8^{\circ}$, which represent the inclination of latitude-optimized fixed-tilt and building-integrated PV systems, respectively), the front glass surface (i.e., uncoated glass versus glass coated with an anti-soiling commercial product), and the maintenance schedule (i.e., no cleaning versus periodic cleaning).

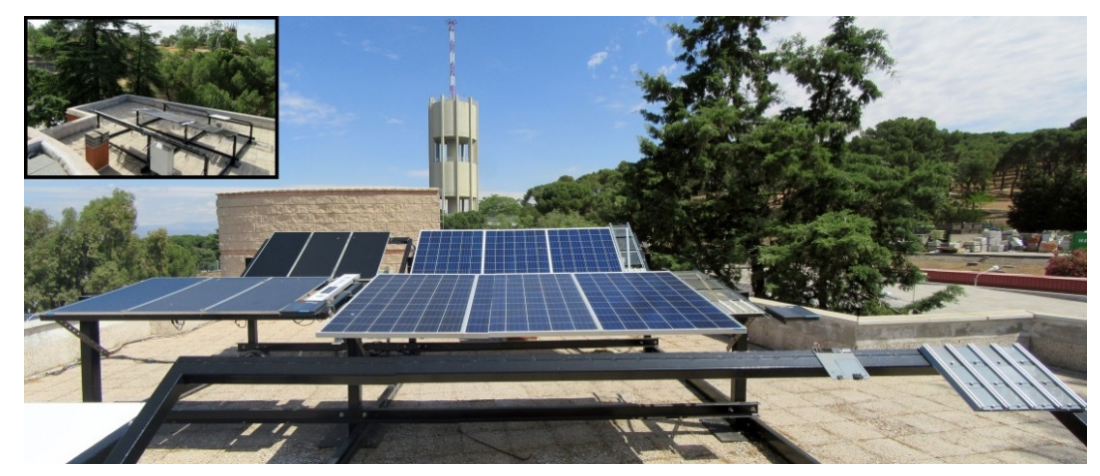

Figure 4. Panoramic view of the rooftop PV system installed for soiling monitoring. 
During the first months of 2019, a conclusion from regular visual inspection was that the soiling layer mainly contained fine dust, although pollen deposition was prevalent during January and February. In accordance with data from a nearby pollen monitoring station (located less than $1 \mathrm{~km}$ away) from the regional palynological network PALINOCAM [100], it could only be identified as Cupressaceae pollen at that time of the year. Pollen deposition on the PV modules was less conspicuous at later dates. In addition to the presence of dust and pollen, bird droppings were regularly noticed on the PV modules.

Our findings were in agreement with other authors reporting that broadly cultivated ornamental species (e.g., cypresses, plane trees, etc.) have a major impact on the airborne pollen spectrum of many populated areas $[15,17]$. The local pollen calendar confirmed that: $(1)$ the airborne total pollen concentration maintains medium-high levels during the first semester of the year and low levels during the second one (see Figure 5) and (2) Cupressaceae pollen is an important contributor to the airborne total pollen from late winter to early spring [101]. In addition, data gathered from the nearby pollen monitoring station during that period showed that Cupressaceae (i.e., in our location, cypresses) and plane tree (Platanus sp.) pollen were almost exclusively responsible for the local airborne pollen from January to mid-March and from mid-March to early April, respectively (Figure 6), while it consisted of a mixture of pollen from other plants (e.g., oak, pine, olive, grass, plantain, etc.) in the following months. Indeed, soiling by cypress pollen was observed when visiting the PV installation from January to mid-March. Contrarily to the local-scale trend indicated by Figure 6, more soiling was noticed during that period than later on. The reason why Cupressaceae pollen prevailed over plane tree pollen as a soiling agent was the proximity of several cypress specimens exceeding the rooftop height. Particularly a single cypress closely adjacent to the PV system had a remarkable soiling impact.

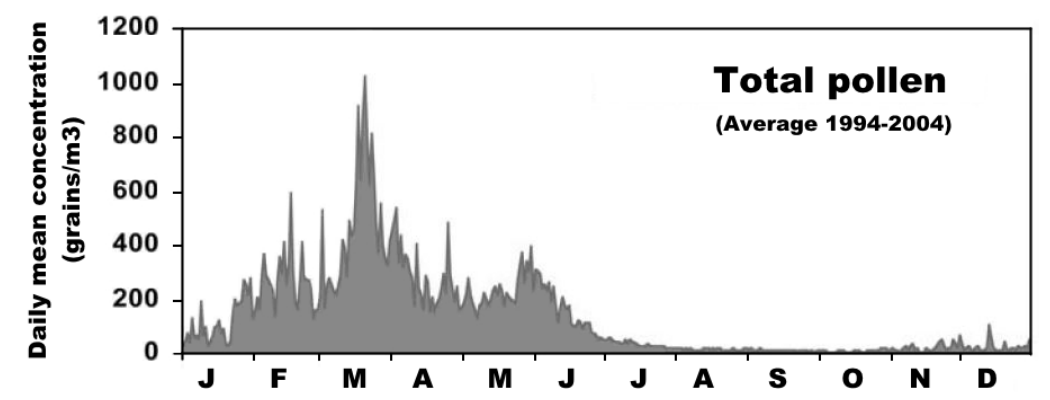

Figure 5. General trend of the local total airborne pollen (adapted from [101]).

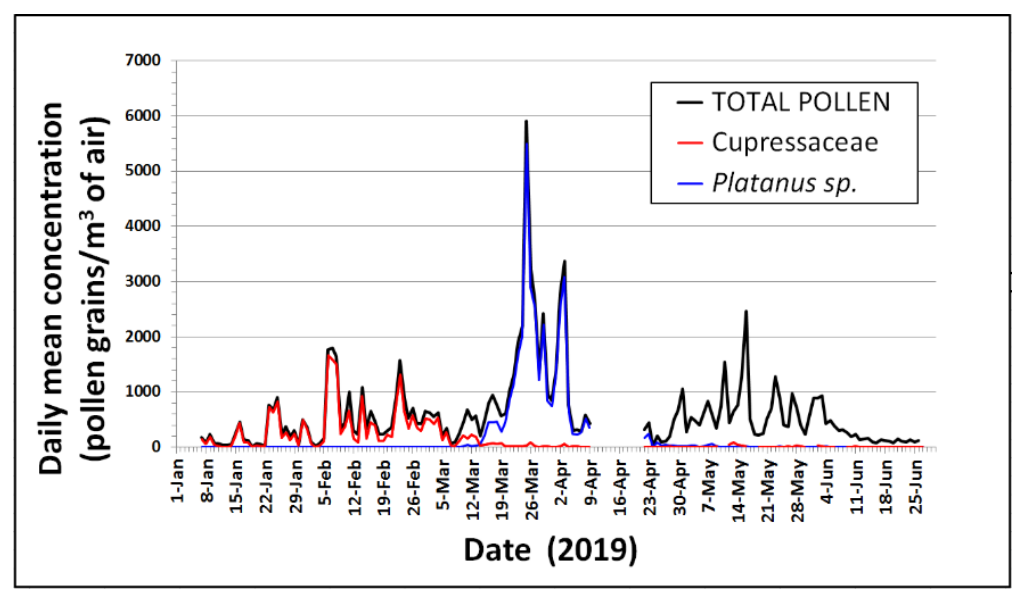

Figure 6. Local airborne pollen (first semester of 2019): comparison of the airborne total pollen with the Cupressaceae and the Platanus sp. contributions. Numerical data gathered from [100].

Interestingly, two different soiling patterns caused by pollen were noticed. In the first place, the PV module surfaces underwent uniform soiling after several rainless weeks (Figure 7a), 
an inevitable fact which, at some point, would require cleaning the PV modules to reduce the soiling losses. Within this general uniformity, some pollen agglomeration distributed homogeneously over the PV module surfaces was observed, perhaps induced by the condensation and evaporation of water drops, provided that morning dew events were regularly noticed during that rainless period. In the second place, non-uniform soiling was observed just after a light rain event: instead of effectively washing pollen away (neither from the $8^{\circ}$-tilted nor from the $35^{\circ}$-tilted module surfaces), $0.7 \mathrm{~mm}$ of rainfall dragged pollen downwards and accumulated it along the bottom edge of the PV modules. While this heterogeneous soiling issue was inevitable in the framed multi-crystalline silicon (mc-Si) modules, it could have been prevented in the frameless cadmium telluride (CdTe) modules by modifying the overhanging supporting structure which artificially retained pollen (Figure $7 \mathrm{~b}$ ). In any case, pollen deposition may cause such a non-uniform soiling pattern during a lengthy rainless springtime period without the need of a light rain event [79].
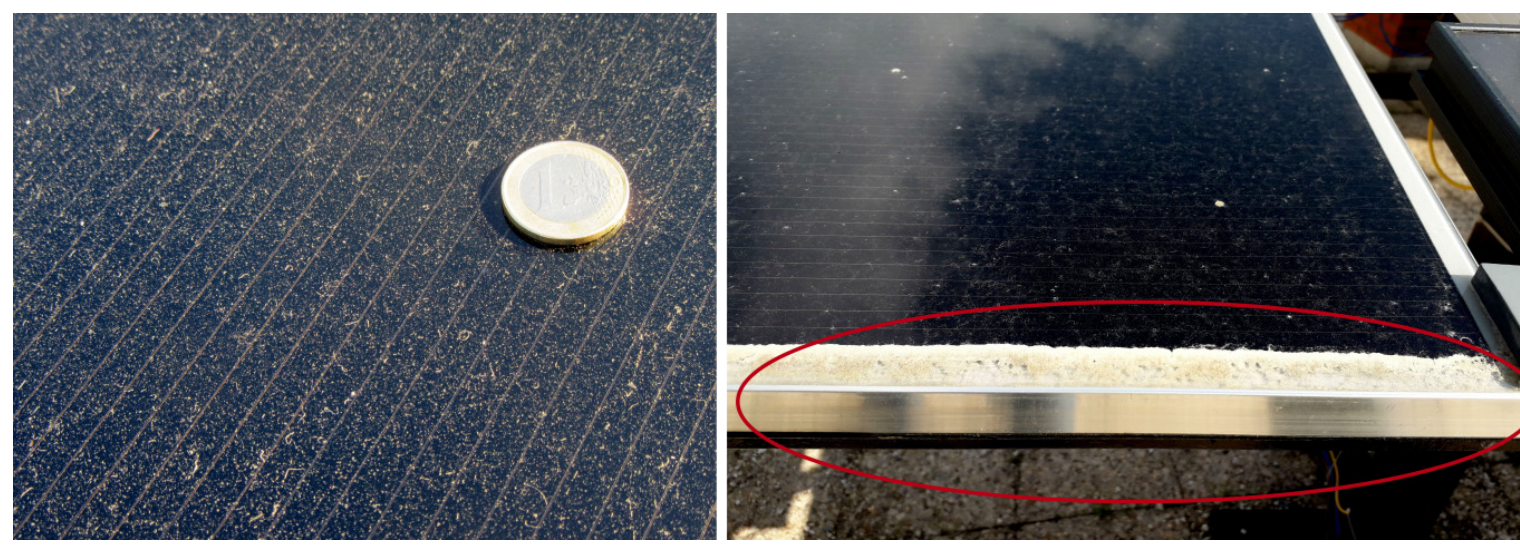

Figure 7. CdTe modules soiled by pollen: (a) uniform soiling and (b) non-uniform soiling.

The international standard IEC 61724 [102] defines the soiling ratio (SR) as the ratio of the actual power output of the PV array under given soiling conditions to the power that would be expected if the PV array were clean and free of soiling. Soiling loss $(S L)$ and soiling ratio are thus complementary, that is, $S L=1-S R$. Overall, during the starting monitoring period (March-June 2019), the $8^{\circ}$-tilted multicrystalline silicon modules of the PV installation endured an average soiling loss of 1.3\% [103], having an impact on the short circuit current rather than on the open-circuit voltage or the fill factor.

As well, two graphics containing some initial performance data have been included for description purposes (Figure 8). These graphs compare the performance of two identical uncoated multicrystalline silicon modules installed at a tilt angle of $8^{\circ}$. Using the short-circuit current data provided by an I-V tracer from two adjacent identical PV modules, being one of them soiled $\left(I_{\mathrm{SC} \text {,soiled }}\right)$ and the other clean $\left(I_{S C, c l e a n}\right)$, to determine the performance ratio $(P R)$ and the soiling ratio $(S R)$ is an accepted practice within the photovoltaic community [104]. Therefore, the performance ratio related to $I_{\mathrm{SC}}$ of both PV modules, $P R_{\text {soiled }}(\%)$ and $P R_{\text {clean }}(\%)$, can be calculated using the following equation [104]:

$$
P R_{\mathrm{Isc}}(\%)=\frac{\sum I_{\mathrm{SC}} / I_{\mathrm{SC}, \mathrm{STC}}}{\sum G_{\mathrm{POA}} / 1000} \times 10
$$

where $G_{\mathrm{POA}}$ is the irradiance in the plane of the array in watts, and $I_{\mathrm{SC}, \mathrm{STC}}$ is the short-circuit current of the PV module at standard test conditions (i.e., in-plane irradiance $1000 \mathrm{~W} / \mathrm{m}^{2}, \mathrm{PV}$ cell temperature $25^{\circ} \mathrm{C}$ and reference spectral irradiance distribution as defined in IEC 60904-3 [105]). Hence, the soiling ratio, $S R(\%)$, can be calculated by comparing the soiling ratio of the soiled module with the soiling ration of a clean one [102]:

$$
S R(\%)=\left(1-\frac{P R_{\text {soiled }}}{P R_{\text {clean }}}\right) \times 100
$$




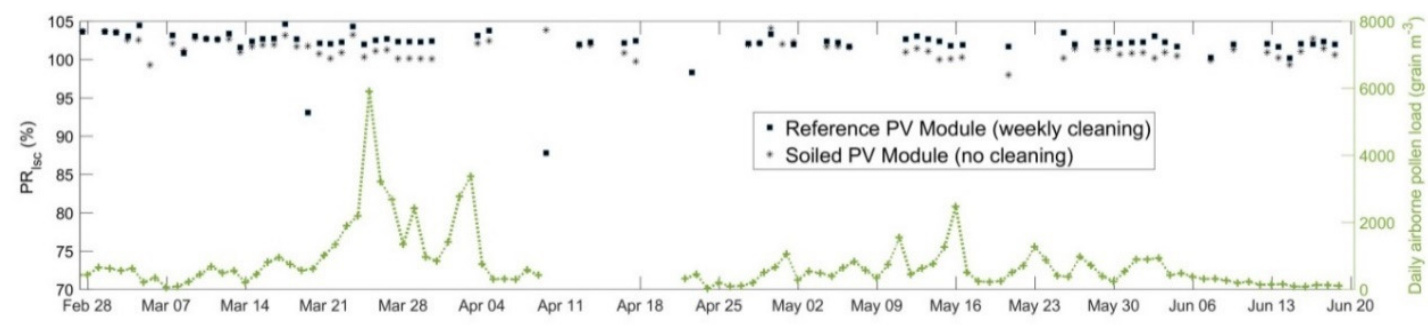

(a)

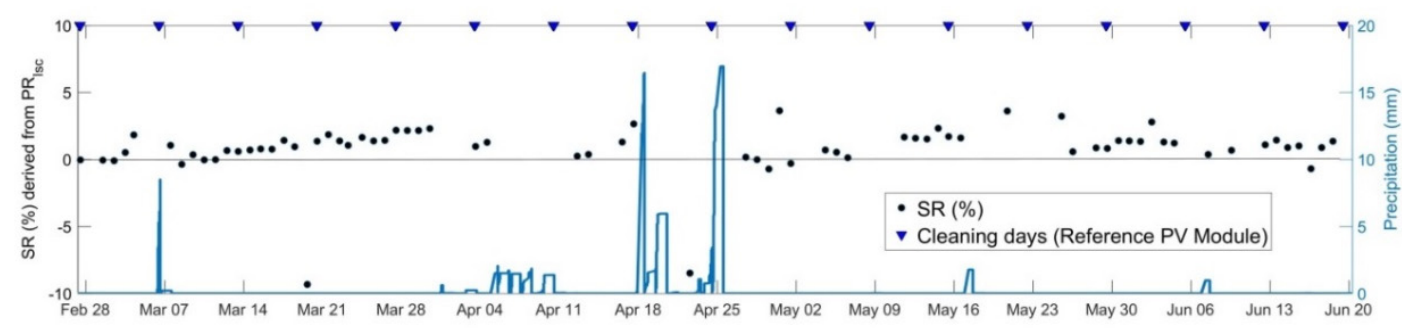

(b)

Figure 8. Performance of two identical mc-Si modules at tilt angle $=8^{\circ}$; one module was cleaned weekly ("reference PV module") and the other was kept uncleaned ("soiled PV module"). (a) performance ratios calculated from short-circuit measurements and daily airborne pollen load and (b) soiling ratios derived from the performance ratios and daily precipitation regime.

In spite of the low degree of soiling underwent by the rooftop PV installation, Figure 8a shows that there was a slight difference between the $P R_{\text {Isc }}$ values of the cleaned and the soiled modules, and Figure $8 \mathrm{~b}$ clearly exhibits a slowly increasing trend over time of $S R$ during the first rainless period (i.e., from 7 March to $28 \mathrm{March}$ ) as well as the performance recovery of the PV modules just after the rainy days of April.

It might have been expected to observe higher soiling rates during February than during March due to the concurrent cypress pollen deposition, which was quite more evident than any other local pollen deposition issue at a later date. Nevertheless, the results during this season were not concluding because: (1) the measured soiling ratios were quite low, (2) the PV modules did not only accumulate pollen, but also dust and other urban pollutants, and (3) it was speculated that the dew events occurring during the cypress pollen season might have removed a fraction of the deposited pollen.

Finally, we focused our interest on artificially analyzing soiling by cypress pollen due to several reasons. Firstly, cypresses are widely spread in the Mediterranean region and release such an enormous amount of pollen that they become responsible for a large part of the total annual amount of airborne pollen in several areas [106]. Secondly, soiling by cypress pollen became relevant to the PV installation, which is not surprising given its abundance in the nearby green areas, boundary hedgerows, etc. A third reason is that fresh pollen can be gathered in large amounts from cypress trees by simply shaking the mature male cones. In fourth place, based on the characteristics of the cypress pollen (i.e., medium grain size, spheroidal shape, release as solitary monads, absence of sticky surface coatings [34]), it seems reasonable to guess that their artificially-deposited soiling layers would fairly approximate to an ideal packaging of loose spherical particles, which facilitates the interpretation of the resulting optical impairment. Moreover, such features make cypress pollen a good representative for pollen of many anemophilous species.

\section{Artificial Soiling Test with Pollen}

\subsection{Methodology}

Artificial soiling tests are regarded as a helpful experimental methodology to understand and quantify the soiling issues. Despite having some constraints to replicate real soiling processes, 
artificial soiling tests performed under laboratory conditions can provide broad information much faster and under much more controlled experimental parameters than outdoor soiling tests performed under environmental conditions. Up to date, artificial soiling tests performed on glass samples or PV modules have been reported for a large number of pollutants: sand, clay, limestone, red soil, silica, calcium carbonate, carbon, ash, and cement, among others [107]. Nevertheless, the present work is the first publication concerning an artificial soiling test carried out with pollen.

Soda lime float glass coupons (approx. $4 \times 4 \times 3 \mathrm{~mm}$ ) were used as substrates. Their surface areas were accurately measured with a caliper gauge. Sample weighting was performed with a microbalance Sartorius TE64 with a precision of $0.1 \mathrm{mg}$. Hemispheric transmittance spectra at near-normal incidence were obtained from $300 \mathrm{~nm}$ to $1800 \mathrm{~nm}$ by means of a Perkin Elmer Lambda ${ }^{\circledR} 900$ spectrophotometer equipped with a Spectralon ${ }^{\circledR}$-coated LabSphere ${ }^{\circledR} 150 \mathrm{~mm}$ integrating sphere. The photometric accuracy of the instrument in transmission mode is $\pm 0.08 \%$ at absorbance equal to 1 and transmission $\pm 0.05 \%$ at absorbance equal to 0.5 . The hemispherical transmittance was measured instead of the normal transmittance to better replicate the incident-light scattering of the soiled glass cover of a PV module. Hence, the glass coupons were cleaned, measured, and weighted and their transmittance spectra were obtained. Next, they were used as substrates to collect fresh cypress (Cupressus sp.) pollen samples from CIEMAT's gardens. After that, the soiled substrates were weighted and analyzed optically again. Finally, the corresponding pollen mass densities $\left(\rho_{\mathrm{A}}\right)$ were calculated as $\rho_{\mathrm{A}}=\Delta M / A$, where $\Delta M$ is the deposited pollen mass and $A$ is the area of the glass coupon.

To improve the sampling representativeness, the set of pollen samples was not prepared by collecting the cypress pollen from a single tree on a particular day, but by collecting it from various trees in different sunny days during the blossoming season. The pollen samples were gathered by selecting cypress specimens with abundant male cones and shaking them manually to release the mature pollen while placing the clean glass coupons close below them, allowing the deposition by sedimentation of soiling layers containing different amounts of pollen. Some of the resulting pollen samples are shown in Figure 9. This sampling procedure imitates, although more vigorously, the natural dispersion of cypress pollen under the wind action. Artificial pollen aggregation was discarded due to the small size, spheroidal shape and non-clumping characteristics of the cypress pollen grains. Next, the pollen samples were carefully transported to the laboratory inside a hermetic box and were analyzed within the first $48 \mathrm{~h}$ after collection. In total, 25 pollen samples were selected for the artificial soiling test, while others were discarded because the resulting pollen layer was inhomogeneous or included some vegetal debris.

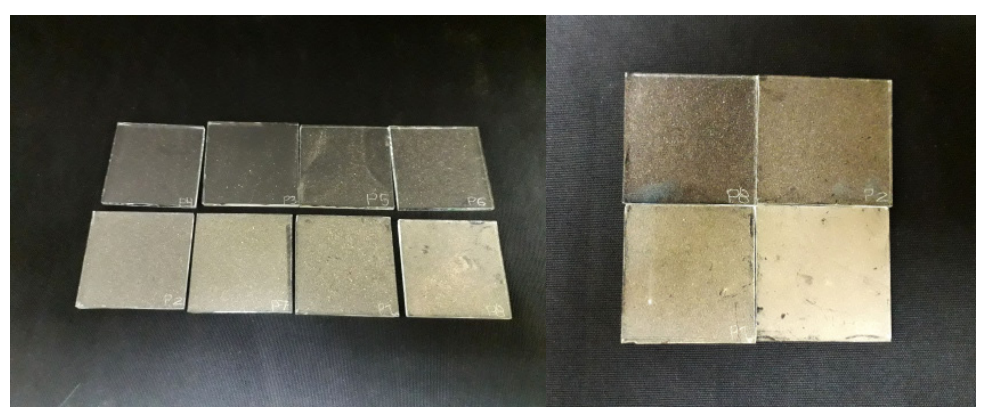

Figure 9. Detail of some artificially soiled pollen samples.

To analyze the effect of pollen deposition on the transmittance, the normalized transmittance of a sample $\left(T_{\text {NORM }}\right)$ is defined as the following ratio:

$$
T_{\text {NORM }}(\%)=\frac{T_{\text {soiled }}(\%)}{T_{\text {clean }}(\%)} \times 100
$$


where $T_{\text {soiled }}$ and $T_{\text {clean }}$ are the transmittances of a glass coupon after having deposited pollen and of the same glass coupon in a clean state, respectively. All the transmittance measurements are hemispherical.

\subsection{Results}

The detrimental effect of the accumulation of cypress pollen on the normalized transmission spectra is shown in Figure 10. While $T_{\text {NORM }}$ dropped by $\sim 5 \%$ and $\sim 12 \%$ for pollen mass densities of $1.4 \mathrm{~g} / \mathrm{m}^{2}$ and $3.1 \mathrm{~g} / \mathrm{m}^{2}$, respectively, it further decreased for higher soiling levels, particularly in the ultraviolet (UV) range. For a given pollen mass density, $T_{\text {NORM }}$ remained constant within a broad wavelength interval, but it decreased at shorter wavelengths. In summary, the transmittance worsened steadily both as the pollen mass density increased and as the wavelength approached to the UV range.

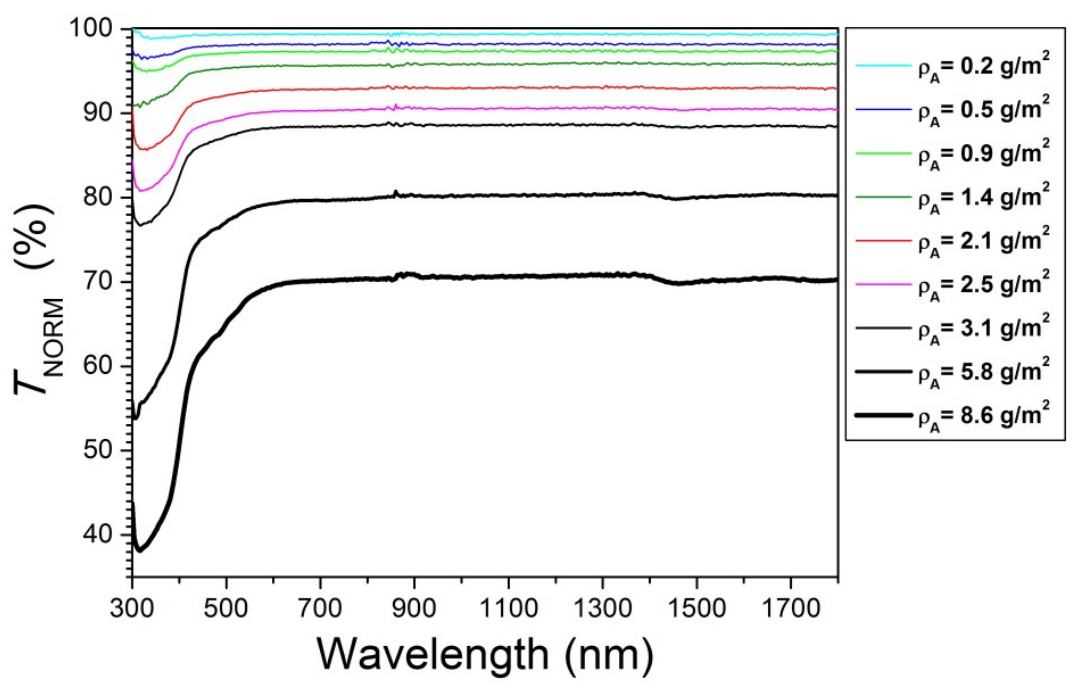

Figure 10. Normalized transmittance $\left(T_{\text {NORM }}\right)$ spectra as a function of the pollen mass density $\left(\rho_{A}\right)$.

Within the visible (VIS) range, cypress pollen exhibited non-selective light scattering. That is, as the pollen particle size (i.e., 29-38 $\mu \mathrm{m}$ in diameter within the genus Cupressus [78]), exceeded the incident wavelength many times, a constant light scattering occurred within the VIS range. An analogous optical behavior was observed for desert dust not exceeding our particle size [97]. Conversely, the observation of a strongly wavelength-dependent transmittance towards the UV range was the reason to complementarily perform some hemispheric reflection measurements. Only a few reflection spectra were measured to prevent an accidental contamination by pollen inside the integrating sphere. Hence, concerning the optical behavior of the glass coupons soiled with pollen, by assuming the following approximation for the absorbance due to pollen:

$$
A_{\text {POLLEN }} \sim A_{\text {soiled }}-A_{\text {clean }}
$$

and substituting the terms of the right-hand side with these definitions:

$$
\begin{aligned}
& A_{\text {soiled }}(\%)=100-T_{\text {soiled }}(\%)-R_{\text {soiled }}(\%) \\
& A_{\text {clean }}(\%)=100-T_{\text {clean }}(\%)-R_{\text {clean }}(\%)
\end{aligned}
$$

the following equation is obtained:

$$
A_{\text {POLLEN }}(\%) \sim T_{\text {clean }}(\%)+R_{\text {clean }}(\%)-T_{\text {soiled }}(\%)-R_{\text {soiled }}(\%)
$$


where $A, T$, and $R$ refer to absorbance, transmittance, and reflectance, respectively, and the subscripts "pollen", "clean", and "soiled" refer only to pollen, to the glass coupon in a clean state, and to the glass coupon soiled with pollen, respectively.

Then, the absorbance spectra of the cypress pollen itself $\left(A_{\text {POLLEN }}\right)$ were calculated and represented (Figure 11), confirming an intense UV absorption which increased with the pollen mass density $\left(\rho_{A}\right)$. This optical behavior would be attributable to the exine, namely the outermost part of the pollen grain wall, which is known to absorb UV light [108]. The major component of the exine is sporopollenin, a complex biopolymer containing UV-absorbing phenolic compounds such as p-coumaric acid and ferulic acid [109]. Given that exineless pollen is restricted to some water-pollinated marine plants [23], this optical behavior should be expected wherever soiling occurs by pollen deposition. However, the absorption intensity would vary not only with the amount of deposited pollen, but also with the vegetal species producing it depending on the thickness of the exine relative to the whole pollen grain size. This absorption peak should be also expected in the event of soiling by fern spores, mosses, and some green algae, provided that their sporoderms also contain sporopollenin [23].

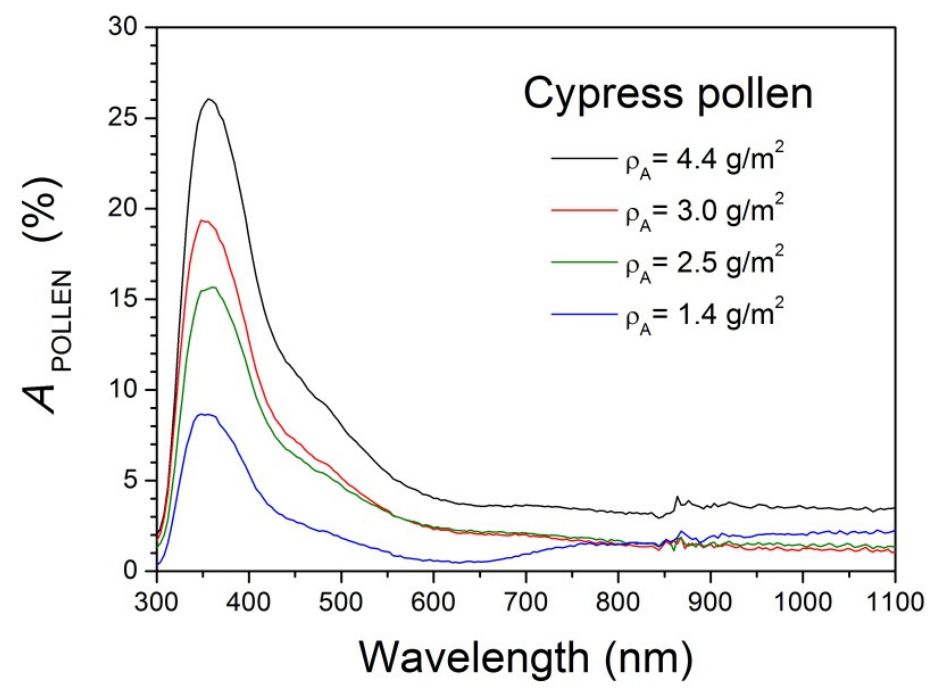

Figure 11. Absorbance spectra of cypress pollen $\left(A_{\text {POLLEN }}\right)$ as a function of the pollen mass density $\left(\rho_{\mathrm{A}}\right)$.

Next, the averaged transmittance $\left(T_{\mathrm{AVE}}\right)$ was obtained by averaging the normalized transmittance ( $T_{\text {NORM }}$ ) over the $300-1200 \mathrm{~nm}$ (instead of the 300-1800 nm) wavelength range. This wavelength interval was chosen because it covers the spectral response of the most common PV technologies [110]. As a result, Figure 12 clearly shows a linear correlation between the pollen mass density $\left(\rho_{\mathrm{A}}\right)$ and the averaged transmittance $\left(T_{\mathrm{AVE}}\right)$ for the 26 analyzed pollen samples. This result agrees with other artificial soiling tests performed with different pollutants (generically referred to as "dust") which showed, at least for low dust densities, a nearly linear relationship between the dust density and both the light transmission and (in case of uniform soiling) the PV efficiency $[7,96,111]$. Nevertheless, some of them reported a deviation from linearity beyond a certain level of soiling. That was because when a portion of the arriving dust particles settled down on the previously deposited ones rather than on a clean surface area, the resulting increase on the dust mass density did not cause as much proportion of light obstruction as observed in an earlier stage [50,51]. From our experimental results, it can be concluded that, in the case of there being a saturation point $[96,112]$ for soiling by pollen, it would exist for a cypress pollen mass density $\left(\rho_{\mathrm{A}}\right)$ above $9.1 \mathrm{~g} / \mathrm{m}^{2}$. Concerning outdoor pollen deposition, pollen mass densities of $0.4-0.5 \mathrm{~g} / \mathrm{m}^{2}$ have been reported for $30^{\circ}$-tilted glass samples during a pollen bloom in a Mediterranean rural area with extensive olive crops [12] (i.e., pollen grains about $20 \mu \mathrm{m}$ in size with a minor content of pollenkitt [44]). 


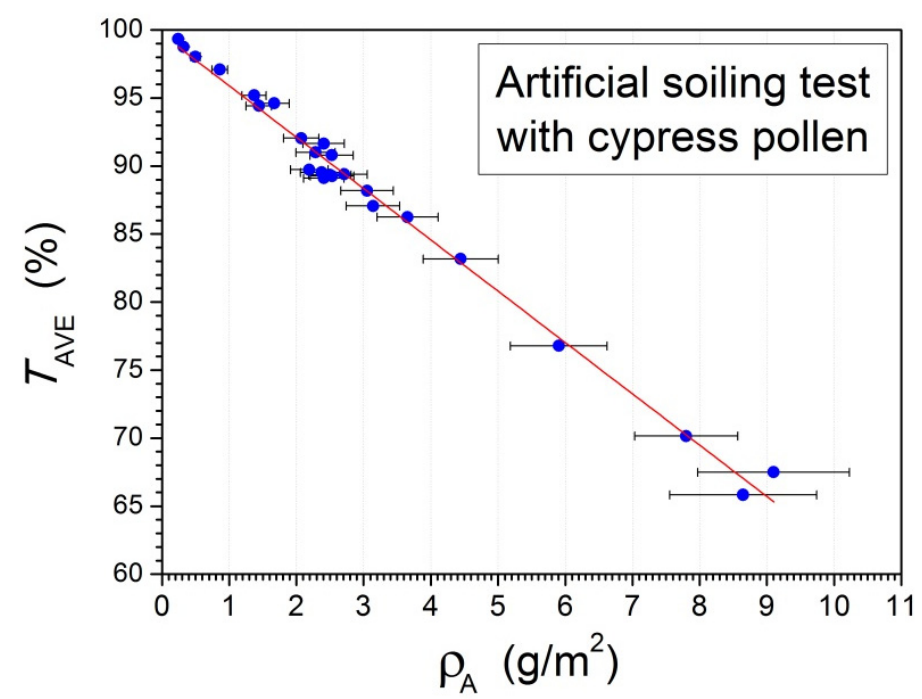

Figure 12. Linear fitting of the averaged transmittance $\left(T_{\mathrm{AVE}}\right)$ as a function of the pollen mass density $\left(\rho_{\mathrm{A}}\right)$.

According to Figure 12, the results of the artificial soiling test achieved a fair good least-square linear fitting (coefficient of determination: $\mathrm{R}^{2}=0.9897$ ) which provided the following correlation with a percentage error of $\pm 1.4 \%$ :

$$
T_{\text {AVE }}(\%)=99.7-3.8 \cdot \rho_{\text {A }}\left(\mathrm{g} / \mathrm{m}^{2}\right)
$$

This confirmed the experimental reproducibility of our artificial soiling test procedure. Besides, the cypress pollen exhibited an excellent linear correlation between the mass accumulation and the optical loss, as it could be expected from the near-ideal geometrical characteristics of their PDUs, which are solitary spheroidal monads [34]. Strictly speaking, this empirical soiling curve would be representative of cypress pollen (i.e., the genus Cupressus), but due to their botanical similarities, it could presumably represent Cupressaceae pollen in general (e.g., also the genus Juniperus, Thuja, Tetraclinis, Taxodium, Callitropsis, etc.). More significant deviations might arise for other plants dispersing pollen with larger differences on its size, shape, or density. Regarding the particle shape, given the same pollen mass density for a soiling layer, pollen grains with irregular shapes could lead to a different optical behavior due to the formation of a heterogeneous soiling layer (i.e., affecting the particle settling orientation, the particle packing density, etc.). For instance, saccate pollen grains of the genera Pinus and Cedrus underwent preferential orientations during settling experiments [20]. Concerning the diameter (d) and the density $(\rho)$ of the pollen grains, these differences can be observed when comparing pollen of Juniperus sp. $\left(\mathrm{d}=18-24 \mu \mathrm{m} ; \rho \sim 640 \mathrm{~kg} / \mathrm{m}^{3}\right)$, Pinus sp. $\left(\mathrm{d} \sim 50-60 \mu \mathrm{m} ; \rho=450-560 \mathrm{~kg} / \mathrm{m}^{3}\right)$, Platanus sp. $\left(\mathrm{d}=19 \mu \mathrm{m}, \rho=920 \mathrm{~kg} / \mathrm{m}^{3}\right)$, and maize $\left(\mathrm{d} 75-90 \mu \mathrm{m} ; \rho=935-1450 \mathrm{~kg} / \mathrm{m}^{3}\right)[13,113,114]$. In the case of Cupressus sp., pollen grain sizes are known $(\mathrm{d}=29-38 \mu \mathrm{m})$ [78] but pollen density values have not been published. Beyond estimating the optical loss from a soiling curve based on a "generic" pollen mass density, estimating its dependence on the grain size, the grain shape and the grain density would provide a deeper insight into this kind of soiling. Hence, additional artificial soiling tests performed with pollen would be valuable to assess the influence of the pollen type. There also remains the question whether the properties of a soiling layer made of pollen would change significantly in case of a long-term outdoor permanence (e.g., due to moisture, UV radiation, etc.). In any case, we expect that this experimental soiling curve will be helpful in order to interpret the energy loss of the PV systems seasonally soiled by pollen in general.

When comparing this soiling curve (Figure 12) with the results of other artificial soiling tests accomplished with different soiling agents, the cypress pollen was found to cause a relatively higher transmittance reduction. For instance, at a dust density of $12 \mathrm{~g} / \mathrm{m}^{2}$, a soda lime glass soiled with desert dust (mostly below $30 \mu \mathrm{m}$ in size; composed by $\mathrm{SiO}_{2}, \mathrm{CaCO}_{3}$, etc.) retained a transmittance around $90 \%$ (300-1200 nm) and showed a weak wavelength dependence [97]. In contrast, a pollen 
density of $8.6 \mathrm{~g} / \mathrm{m}^{2}$ reduced the transmittance to around $70 \%$ and $40 \%$ in the VIS and UV ranges, respectively (Figure 10). Other authors reported that dust mass densities of $10 \mathrm{~g} / \mathrm{m}^{2}$ reduced the transmittance to $99 \%$ (white sand, $250 \mu \mathrm{m}$ ), 90\% (clay, $68 \mu \mathrm{m}$ ), and $81 \%$ (cement, $10 \mu \mathrm{m}$ ) [7]. Interestingly, cypress pollen shows a higher soiling capacity (by extrapolation to $\rho_{\mathrm{A}}=10 \mathrm{~g} / \mathrm{m}^{2}, T_{\mathrm{AVE}}=61.7 \%$ ) than cement dust despite a smaller particle size and a stronger VIS absorption were expected for the latter.

These transmittance differences made us speculate about other influencing factors. Some technical testing aspects might contribute to such discrepancies (e.g., differences on the optical instrument and the light source, on the measured wavelength range, on the sample manipulation, etc.). Furthermore, while the soiling particles are known to hinder the glass transmission depending on their nature, size, and density [95], different pollutants at identical surface mass densities, even having comparable particle diameters, might lead to different transmittance impairments due to physical reasons (e.g., differences on the glass composition and thickness, on the particle stacking depending on the soiling particle characteristics, on particle settling constrains due to specific artificial soiling methods, etc.).

As an important effect on PV generation, one further consideration: the intense optical absorption observed at shorter wavelengths (i.e., towards the UV range) suggests that a heavy soiling by pollen might impact the solar energy production differently depending on the PV module type because of the differences on the spectral response among the PV technologies [110]. Following this reasoning, wide-bandgap technologies (i.e., amorphous silicon and CdTe modules) would become more affected by pollen deposition than crystalline silicon and copper indium gallium diselenide (CIGS) modules.

\section{Conclusions}

Pollen may become a seasonal, local-scale soiling issue affecting the PV performance not only in large agricultural and forest areas, but also in urban areas due to the ornamental vegetation in parks, gardens, tree-lined avenues, etc. Anemophilous (i.e., wind-pollinated) plants have a much higher pollen-related soiling potential than entomophilous (i.e., insect-pollinated) ones. According to the literature and local observations, PV modules soiled by pollen can be effectively washed off by rainfall excepting light rain events and photocatalytic anti-soiling coatings could improve their performance.

Pollen blooms can be predicted or detected by consulting the local pollen calendar or real-time data from local pollen monitoring stations, respectively. In recent times, airborne pollen monitoring has been generalized in many populated areas through the air quality control policies. It should be noted that there is not a straightforward correlation between the airborne pollen concentration and the degree of soiling by pollen in order to forecast the energy output. This might be attempted case-by-case through statistical analyses when having enough long-term data concerning both the PV performance and the local aerobiological information. Still, local pollen calendars and local pollen monitoring data can help to mitigate soiling by pollen by planning the maintenance operations of PV installations accordingly.

Regarding the rooftop PV system installed in a gardened semi-urban area, significant soiling by cypress pollen was noticed from late winter to early spring. Pollen deposition caused both uniform and non-uniform soiling patterns: while homogeneous soiling was observed during rainless conditions, pollen became accumulated along the bottom edge of the PV modules after a light rain event. Based on our observations, the PV installation was more affected by the presence of a nearby pollen source (i.e., cypresses located at meters or few tens of meters away) than by the vegetation causing record airborne pollen levels at local scale.

In addition, the results of an artificial soiling test carried out with pollen have been presented. Pollen samples were prepared by using soda lime float glass coupons as substrates and fresh cypress (Cupressus sp.) pollen as the soiling agent. The hemispheric transmittance measurements of the soiled samples were normalized by the hemispheric transmittance spectra of the clean substrates and subsequently averaged over a wide wavelength range (300-1200 nm) coincident with the spectral 
response of most PV technologies. Among the results, the averaged transmittance $\left(T_{\mathrm{AVE}}\right)$ decreased gradually with the increase of the pollen mass density within the whole experimental range, following the linear relationship $T_{\mathrm{AVE}}(\%)=99.7-3.8 \cdot \rho_{\mathrm{A}}\left(\mathrm{g} / \mathrm{m}^{2}\right)$ up to a value of $T_{\mathrm{AVE}}=65.1 \%$ for $\rho_{\mathrm{A}}=9.1 \mathrm{~g} / \mathrm{m}^{2}$. This experimental soiling curve is expected to help into the interpretation of the PV energy loss in areas seasonally impacted by pollen sedimentation. Interestingly, for a given pollen mass density $\left(\rho_{\mathrm{A}}\right)$, while the glass transmittance remained constant within the VIS range due to non-selective light scattering, a higher transmittance loss occurred in the UV range, seemingly due to intense UV light absorption by the sporopollenin content of the pollen grain exine. This effect, which is extensive to all relevant pollens, might be particularly detrimental for wide-bandgap PV technologies (i.e., with narrow spectral responses).

Achieving artificial soiling tests with pollen of more vegetal species, especially from others which also cause high airborne pollen levels, would be desirable to better understand the role of pollen as a soiling agent. We speculate that the soiling behavior of pollen might differ between saccate and non-saccate pollen and especially when comparing non-aggregated pollen (which is the typical case for anemophilous pollen) and aggregated pollen (i.e., pollen clumps: several pollen grains joined together by pollenkitt or another sticky surface-covering material).

Author Contributions: C.S.S. bibliographic research, artificial soiling test, writing, and manuscript preparation, J.P.M. and N.M.C. funding and supervision, PV monitoring data and manuscript revision. All authors have read and agreed to the published version of the manuscript.

Funding: This research was supported by the PVCastSOIL Project (ENE2017-469 83790-C3-1/-2/-3), which is funded by the Ministerio de Economía y Competitividad (MINECO) and co-financed by the European Regional Development Fund (ERDF).

Conflicts of Interest: The authors declare that they have no known competing financial interests or personal relationships that could have appeared to influence the work reported in this paper.

\section{Abbreviations, Acronyms and Nomenclature}

$\begin{array}{ll}A & \text { area of a glass coupon; } \\ A_{\text {clean }} & \text { absorbance of a clean glass coupon; } \\ A_{\text {POLLEN }} & \text { absorbance of pollen; } \\ A_{\text {soiled }} & \text { absorbance of a soiled glass coupon; } \\ \text { AOD } & \text { Aerosol Optical Depth; } \\ A P I & \text { Annual Pollen Index; } \\ \text { APIn } & \text { Annual Pollen Integral; } \\ \text { C. } & \text { genera Cupressus; } \\ \text { CdTe } & \text { cadmium telluride; } \\ \text { Cfb } & \text { temperate fully-humid climate with warm summer; } \\ \text { CIGS } & \text { copper indium gallium diselenide; } \\ \text { Csa } & \text { temperate climate with hot-dry summer; } \\ \text { EDS } & \text { electrodynamic screen; } \\ \text { GPOA } & \text { irradiance in the plane of the array; } \\ H & \text { height of pollen release; } \\ I_{\mathrm{SC}} & \text { short-circuit current; } \\ I_{\mathrm{SC}, \text { clean }} & \text { short-circuit current of a clean photovoltaic module; } \\ I_{\mathrm{SC}, \text { soiled }} & \text { short-circuit current of a soiled photovoltaic module; } \\ I_{\mathrm{SC}, \mathrm{STC}} & \text { short-circuit current under standard test conditions; } \\ \text { mc-Si } & \text { multicrystalline silicon; } \\ \text { PDU } & \text { pollen dispersal unit; } \\ \text { PM2.5 } & \text { suspended particulate matter below 2.5 } \mu \text { m in diameter; } \\ \text { PM10 } & \text { suspended particulate matter below } 10 \mu \mathrm{m} \text { in diameter; } \\ P R_{\mathrm{Isc}} & \text { performance ratio related to ISC; } \\ P R_{\text {clean }} & \text { performance ratio of a clean photovoltaic module; } \\ & \end{array}$




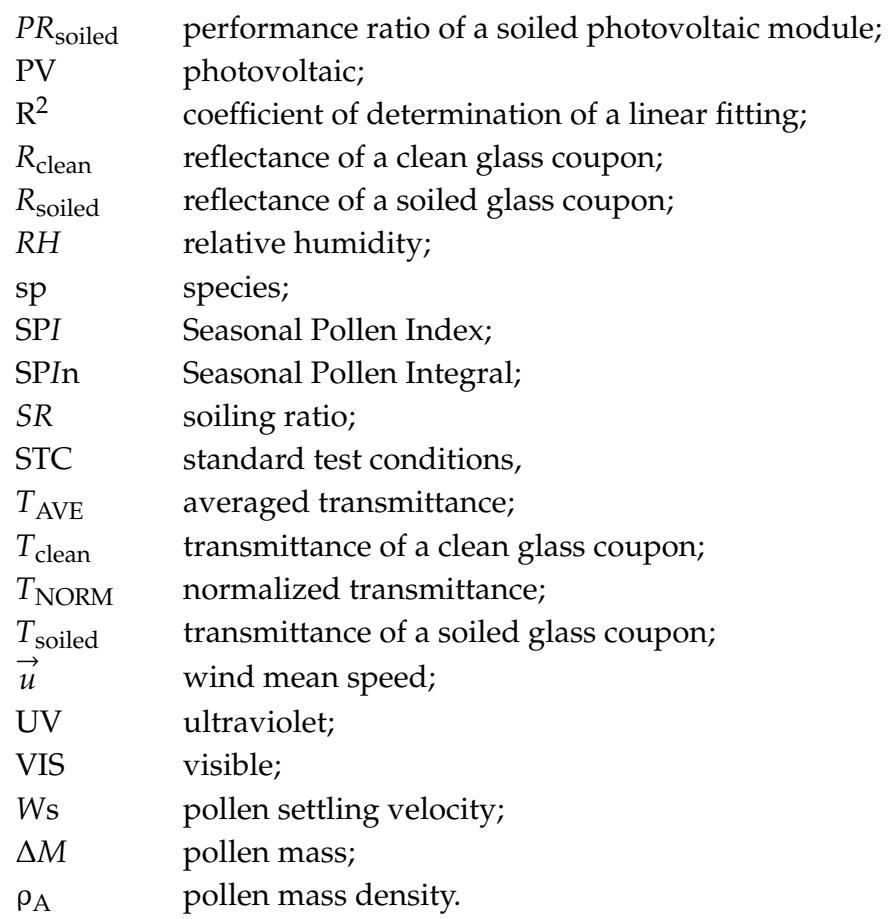

\section{References}

1. Costa, S.C.S.; Diniz, A.S.A.C.; Kazmerski, L.L. Solar energy dust and soiling R\&D progress: Literature review update for 2016. Renew. Sustain. Energy Rev. 2018, 82, 2504-2536. [CrossRef]

2. Sarver, T.; Al-Qaraghuli, A.; Kazmerski, L.L. A comprehensive review of the impact of dust on the use of solar energy: History, investigations, results, literature, and mitigation approaches. Renew. Sustain. Energy Rev. 2013, 22, 698-733. [CrossRef]

3. Gupta, V. Impact of dust deposition on solar photovoltaic panel in desert region: review. Int. J. Electron. Electr. Comput. Syst. IJEECS 2017, 6, 125-140.

4. International Energy Agency. Assessment of Photovoltaic Module Failures in the Field; International Energy Agency: Paris, France, 2017; ISBN 9783906042541.

5. Sayyah, A.; Horenstein, M.N.; Mazumder, M.K. Energy yield loss caused by dust deposition on photovoltaic panels. Sol. Energy 2014, 107, 576-604. [CrossRef]

6. Maghami, M.R.; Hizam, H.; Gomes, C.; Radzi, M.A.; Rezadad, M.I.; Hajighorbani, S. Power loss due to soiling on solar panel: A review. Renew. Sustain. Energy Rev. 2016, 59, 1307-1316. [CrossRef]

7. Appels, R.; Lefevre, B.; Herteleer, B.; Goverde, H.; Beerten, A.; Paesen, R.; De Medts, K.; Driesen, J.; Poortmans, J. Effect of soiling on photovoltaic modules. Sol. Energy 2013, 96, 283-291. [CrossRef]

8. Figgis, B.; Ennaoui, A.; Ahzi, S.; Remond, Y. Review of PV soiling measurement methods. In Proceedings of the 2016 International Renewable and Sustainable Energy Conference (IRSEC), Marrakech, Morocco, 14-17 November 2016; pp. 176-180. [CrossRef]

9. Ilse, K.K.; Figgis, B.W.; Naumann, V.; Hagendorf, C.; Bagdahn, J. Fundamentals of soiling processes on photovoltaic modules. Renew. Sustain. Energy Rev. 2018, 98, 239-254. [CrossRef]

10. Jones, A.M.; Harrison, R.M. The effects of meteorological factors on atmospheric bioaerosol concentrations A review. Sci. Total Environ. 2004, 326, 151-180. [CrossRef]

11. Bustillo, M.G.; Laín, C.S.; Ruiz, E.A.; Iriarte, J.M.O. Polen atmosférico en la Comunidad de Madrid; Documento Técnico de Salud Pública 70; Dirección General de Salud Pública de la Consejería de Sanidad de la Comunidad de Madrid: Madrid, Spain, 2001; ISBN 84-451-2018-2.

12. Conceição, R.; Silva, H.G.; Mirão, J.; Gostein, M.; Fialho, L.; Narvarte, L.; Collares-Pereira, M. Saharan dust transport to Europe and its impact on photovoltaic performance: A case study of soiling in Portugal. Sol. Energy 2018, 160, 94-102. [CrossRef] 
13. Sicard, M.; Izquierdo, R.; Jorba, O.; Alarcón, M.; Belmonte, J.; Comerón, A.; De Linares, C.; Baldasano, J.M. Modelling of pollen dispersion in the atmosphere: Evaluation with a continuous $1 \beta+1 \delta$ lidar. EPJ Web Conf. 2018, 176, 05006. [CrossRef]

14. Buters, J.T.M.; Antunes, C.; Galveias, A.; Bergmann, K.C.; Thibaudon, M.; Galán, C.; Schmidt-Weber, C.; Oteros, J. Pollen and spore monitoring in the world. Clin. Transl. Allergy 2018, 8, 1-5. [CrossRef] [PubMed]

15. Rojo, J.; Rapp, A.; Lara, B.; Fernández-González, F.; Pérez-Badia, R. Effect of land uses and wind direction on the contribution of local sources to airborne pollen. Sci. Total Environ. 2015, 538, 672-682. [CrossRef] [PubMed]

16. Hidalgo, P.J.; Galán, C.; Domínguez, E. Male phenology of three species of Cupressus: Correlation with airborne pollen. Trees-Struct. Funct. 2003, 17, 336-344. [CrossRef]

17. Ziello, C.; Sparks, T.H.; Estrella, N.; Belmonte, J.; Bergmann, K.C.; Bucher, E.; Brighetti, M.A.; Damialis, A.; Detandt, M.; Galán, C.; et al. Changes to airborne pollen counts across europe. PLoS ONE 2012, 7, e34076. [CrossRef] [PubMed]

18. Galán, C.; Alcázar, P.; Oteros, J.; García-Mozo, H.; Aira, M.J.; Belmonte, J.; De la Guardia, C.D.; Fernández-González, D.; Gutiérrez-Bustillo, M.; Moreno-Grau, S.; et al. Airborne pollen trends in the Iberian Peninsula. Sci. Total Environ. 2016, 550, 53-59. [CrossRef]

19. Rantio-Lehtimäki, A.H. Short, medium and long range transported airborne particles in viability and antigenicity analyses. Aerobiologia 1994, 10, 175-181. [CrossRef]

20. Hirose, Y.; Osada, K. Terminal settling velocity and physical properties of pollen grains in still air. Aerobiologia 2016, 32, 385-394. [CrossRef]

21. Sofiev, M.; Belmonte, J.; Regula, G.; Izquierdo, R.; Smith, M.; Dahl, Å.; Siljamo, P. Airborne pollen transport. In Allergenic pollen. A Review of the Production, Release, Distribution and Health Impacts; Sofiev, M., Bergmann, K.C., Eds.; Springer: Dordrecht, The Netherlands, 2013; pp. 127-159. ISBN 978-94-007-4880.

22. Sjögren, P.; van der Knaap, W.O.; Huusko, A.; van Leeuwen, J.F.N. Pollen productivity, dispersal, and correction factors for major tree taxa in the Swiss Alps based on pollen-trap results. Rev. Palaeobot. Palynol. 2008, 152, 200-210. [CrossRef]

23. Pacini, E.; Hesse, M. Uncommon pollen walls: Reasons and consequences. Verh. Zool.-Bot. Ges. Österreich 2012, 148-149, 291-306.

24. Pacini, E.; Franchi, G.G. Pollen grain sporoderm and types of dispersal units. Acta Soc. Bot. Pol. 1999, 68, 299-305. [CrossRef]

25. Erdtman, G. Pollen Morphology and Plant Taxonomy: Angiosperms. An Introduction to the Study of Pollen Grains and Spores; Brill: Leiden, The Netherlands, 1986; ISBN 9004081224.

26. Sénéchal, H.; Visez, N.; Charpin, D.; Shahali, Y.; Peltre, G.; Biolley, J.P.; Lhuissier, F.; Couderc, R.; Yamada, O.; Malrat-Domenge, A.; et al. A review of the effects of major atmospheric pollutants on pollen grains, pollen content, and allergenicity. Sci. World J. 2015, 2015, 940243. [CrossRef]

27. Ribeiro, H.; Guimarães, F.; Duque, L.; Noronha, F.; Abreu, I. Characterisation of particulate matter on airborne pollen grains. Environ. Pollut. 2015, 206, 7-16. [CrossRef] [PubMed]

28. Kottek, M.; Grieser, J.; Beck, C.; Rudolf, B.; Rubel, F. World map of the Köppen-Geiger climate classification updated. Meteorol. Zeitschrift 2006, 15, 259-263. [CrossRef]

29. Ackerman, J.D. Abiotic pollen and pollination: ecological, functional, and evolutionary perspectives. Plant Syst. Evol. 2000, 222, 167-185. [CrossRef]

30. Tormo, R.; Muñoz, A.; Silva, I.; Gallardo, F. Pollen production in anemophilous trees. Grana 1996, 35, 38-46. [CrossRef]

31. Hesse, M. Pollenkitt and viscin threads: Their role in cementing pollen grains. Grana 1981, 20, 145-152. [CrossRef]

32. Pope, F.D. Pollen grains are efficient cloud condensation nuclei. Environ. Res. Lett. 2010, 5, 3-7. [CrossRef]

33. Halbritter, H.; Ulrich, S.; Grímsson, F.; Weber, M.; Zetter, R.; Hesse, M.; Buchner, R.; Svojtka, M.; Frosch-Radivo, A. Illustrated Pollen Terminology; Springer International Publishing: Cham, Switzerland, 2018; ISBN 9783319713649.

34. PalDat-A Palynological Database. Available online: https://www.paldat.org/ (accessed on 15 June 2020).

35. Grega, L.; Anderson, S.; Cheetham, M.; Clemente, M.; Colletti, A.; Moy, W.; Talarico, D.; Thatcher, S.L.; Osborn, J.M. Aerodynamic characteristics of saccate pollen grains. Int. J. Plant Sci. 2013, 174, 499-510. [CrossRef] 
36. Schwendemann, A.B.; Wang, G.; Mertz, M.L.; McWilliams, R.T.; Thatcher, S.L.; Osborn, J.M. Aerodynamics of saccate pollen and its implications for wind pollination. Am. J. Bot. 2007, 94, 1371-1381. [CrossRef]

37. Servicio de Alergología de Alcoy (Valencia, España), Fichas Descriptivas de Polen. Available online: http://alcoy.san.gva.es/alercoy/fichas/ (accessed on 15 June 2020).

38. Hofmann, F.; Otto, M.; Wosniok, W. Maize pollen deposition in relation to distance from the nearest pollen source under common Cultivation-Results of 10 years of monitoring (2001 to 2010). Environ. Sci. Eur. 2014, 26,1-14. [CrossRef]

39. Timerman, D.; Greene, D.F.; Ackerman, J.D.; Kevan, P.G.; Nardone, E. Pollen aggregation in relation to pollination vector. Int. J. Plant Sci. 2014, 175, 681-687. [CrossRef]

40. Pacini, E.; Franchi, G.G. Types of pollen dispersal units and pollen competition. In Anther and Pollen; Clément, C., Pacini, E., Audran, J.-C., Eds.; Springer: Berlin/Heidelberg, Germnay, 2011; pp. 1-11.

41. Harder, L.D.; Johnson, S.D. Function and evolution of aggregated pollen in Angiosperms. Int. J. Plant Sci. 2008, 169, 59-78. [CrossRef]

42. Martin, M.D.; Chamecki, M.; Brush, G.S.; Meneveau, C.; Parlange, M.B. Pollen clumping and wind dispersal in an invasive angiosperm. Am. J. Bot. 2009, 96, 1703-1711. [CrossRef]

43. Pacini, E.; Hesse, M. Pollenkitt-Its composition, forms and functions. Flora Morphol. Distrib. Funct. Ecol. Plants 2005, 200, 399-415. [CrossRef]

44. Lin, H.; Gómez, I.; Meredith, J.C. Pollenkitt wetting nechanism enables species-specific tunable pollen adhesion. Langmuir 2013, 29, 3012-3023. [CrossRef] [PubMed]

45. Hesse, M. Pollen wall stratification and pollination. Plant Syst. Evol. 2000, 222, 1-17. [CrossRef]

46. Taylor, P.E.; Flagan, R.; Miguel, A.G.; Valenta, R.; Glovsky, M.M. Birch pollen rupture and the release of aerosols of respirable allergens. Clin. Exp. Allergy 2004, 34, 1591-1596. [CrossRef] [PubMed]

47. Suphioglu, C. Thunderstorm asthma due to grass pollen. Int. Arch. Allergy Immunol. 1998, 116, $253-260$. [CrossRef] [PubMed]

48. Azarkan, N.; Chassard, G.; Visez, N.; Poncet, P.; Naas, O.; Choël, M.; Sénéchal, H.; Sutra, J.-P. Wind-induced mechanical rupture of birch pollen: Potential implications for allergen dispersal. J. Aerosol Sci. 2015, 89, 77-84. [CrossRef]

49. Tang, M.; Gu, W.; Ma, Q.; Li, Y.J.; Zhong, C.; Li, S.; Yin, X.; Huang, R.-J.; He, H.; Wang, X. Water adsorption and hygroscopic growth of six anemophilous pollen species: The effect of temperature. Atmos. Chem. Phys. 2019, 19, 2247-2258. [CrossRef]

50. Chen, L.; Chen, Y.; Chen, L.; Gu, W.; Peng, C.; Luo, S.; Song, W.; Wang, Z.; Tang, M. Hygroscopic properties of 11 pollen species in China. ACS Earth Sp. Chem. 2019, 3, 2678-2683. [CrossRef]

51. Griffiths, P.T.; Borlace, J.S.; Gallimore, P.J.; Kalberer, M.; Herzog, M.; Pope, F.D. Hygroscopic growth and cloud activation of pollen: a laboratory and modelling study. Atmos. Sci. Lett. 2012, 13, 289-295. [CrossRef]

52. Danti, R.; Della Rocca, G.; Calamassi, R.; Mori, B.; Mariotti Lippi, M. Insights into a hydration regulating system in Cupressus pollen grains. Ann. Bot. 2011, 108, 299-306. [CrossRef] [PubMed]

53. Chichiricco, G.; Pacini, E. Cupressus arizonica pollen wall zonation and in vitro hydration. Plant Syst. Evol. 2008, 270, 231-242. [CrossRef]

54. Conceição, R.; Silva, H.G.; Mirão, J.; Collares-Pereira, M. Organic soiling: The role of pollen in PV module performance degradation. Energies 2018, 11, 294. [CrossRef]

55. Kendel, A.; Zimmermann, B. Chemical Analysis of Pollen by FT-Raman and FTIR Spectroscopies. Front. Plant Sci. 2020, 11, 1-19. [CrossRef]

56. McDonald, J.E. Pollen wettability as a factor in washout by raindrops. Science 1964, 143, 1180-1181. [CrossRef]

57. Lin, H.; Lizarraga, L.; Bottomley, L.A.; Meredith, J.C. Effect of water absorption on pollen adhesion. J. Colloid Interface Sci. 2015, 442, 133-139. [CrossRef]

58. Ito, S.; Gorb, S.N. Fresh "pollen adhesive" weakens humidity-dependent pollen adhesion. ACS Appl. Mater. Interfaces 2019, 11, 24691-24698. [CrossRef]

59. Vaknin, Y.; Gan-Mor, S.; Bechar, A.; Ronen, B.; Eisikowitch, D. The role of electrostatic forces in pollination. Plant Syst. Evol. 2005, 222, 133-142. [CrossRef]

60. Law, S.E. Agricultural electrostatic spray application: A review of significant research and development during the 20th century. J. Electrostat. 2001, 51, 25-42. [CrossRef] 
61. Takikawa, Y.; Matsuda, Y.; Nonomura, T.; Kakutani, K.; Kusakari, S.I.; Toyoda, H. An electrostatic-barrier-forming window that captures airborne pollen grains to prevent pollinosis. Int. J. Environ. Res. Public Health 2017, 14, 82. [CrossRef] [PubMed]

62. Bowker, G.E.; Crenshaw, H.C. Electrostatic forces in wind-pollination-Part 1: Measurement of the electrostatic charge on pollen. Atmos. Environ. 2007, 41, 1587-1595. [CrossRef]

63. Erickson, E.H.; Buchmann, S.L. Electrostatics and pollination. In Handbook of Experimental Pollination Biology; Jones, C.E., Little, R.J., Eds.; Scientific and Academic Editions: New York, NY, USA, 1993; pp. 173-184.

64. Okubo, A.; Levin, S.A. A theoretical framework for data analysis of wind dispersal of seeds and pollen. Ecology 1989, 70, 329-338. [CrossRef]

65. Giddings, G. Modelling the spread of pollen from Lolium perenne. The implications for the release of wind-pollinated transgenics. Theor. Appl. Genet. 2000, 100, 971-974. [CrossRef]

66. Adams-Groom, B.; Skjøth, C.A.; Baker, M.; Welch, T.E. Modelled and observed surface soil pollen deposition distance curves for isolated trees of Carpinus betulus, Cedrus atlantica, Juglans nigra and Platanus acerifolia. Aerobiologia 2017, 33, 407-416. [CrossRef]

67. Bricchi, E.; Frenguelli, G.; Mincigrucci, G. Experimental results about Platanus pollen deposition. Aerobiologia 2000, 16, 347. [CrossRef]

68. Dahl, Å.; Galán, C.; Hajkova, L.; Pauling, A.; Sikoparija, B.; Smith, M.; Vokou, D. The onset, course and intensity of the pollen season. In Allergenic Pollen. A Review of the Production, Release, Distribution and Health Impacts; Sofiev, M., Bergmann, K.-C., Eds.; Springer: Dordrecht, The Netherlands, 2013; pp. $29-70$.

69. Feehan, J.; Harley, M.; Minnen, J. Climate change in Europe. Impact on terrestrial ecosystems and biodiversity. A review. Agron. Sustain. Dev. 2009, 29, 409-421. [CrossRef]

70. Bastl, K.; Kmenta, M.; Berger, U.E. Defining pollen seasons: background and recommendations. Curr. Allergy Asthma Rep. 2018, 18, 73. [CrossRef]

71. Galán, C.; Tormo, R.; Cuevas, J.; Infante, F.; Domínguez, E. Theoretical daily variation patterns of airborne pollen in the south-west of Spain. Grana 1991, 30, 201-209. [CrossRef]

72. Irdi, G.A.; Jones, J.R.; White, C.M. Pollen and fungal spore sampling and analysis: Statistical evaluations. Grana 2002, 41, 44-47. [CrossRef]

73. Worldwide Map of Pollen Monitoring Stations. Available online: https://www.zaum-online.de/pollen/pollenmonitoring-map-of-the-world.html (accessed on 15 June 2020).

74. Bortenschlager, S. Aspects of pollen morphology in the Cupressaceae. Grana 1990, 29, 129-138. [CrossRef]

75. Kurmann, M.H. Pollen morphology and ultrastructure in the Cupressaceae. Acta Bot. Gall. 1994, 141, $141-147$. [CrossRef]

76. Galán, C.; Fuillerat, M.J.; Comtois, P.; Domínguez-Vilches, E. Bioclimatic factors affecting daily Cupressaceae flowering in southwest Spain. Int. J. Biometeorol. 1998, 41, 95-100. [CrossRef]

77. Belmonte, J.; Canela, M.; Guàrdia, R.; Guàrdia, R.A.; Sbai, L.; Vendrell, M.; Cariñanos, P.; Díaz de la Guardia, C.; Dopazo, A.; Fernández, D.; et al. Aerobiological dynamics of the Cupressaceae pollen in Spain, 1992. Polen 1999, 10, 27-38.

78. Danti, R.; Della Rocca, G.; Mori, B.; Torraca, G.; Calamassi, R.; Lippi, M.M. Old world and new world Cupressus pollen: morphological and cytological remarks. Plant Syst. Evol. 2010, 287, 167-177. [CrossRef]

79. Häberlin, H. Solar modules and solar generators. In Photovoltaics: System Design and Practice; Häberlin, H., Ed.; Wiley: Hoboken, NJ, USA, 2012; p. 732. ISBN 9783540773405.

80. Häberlin, H.; Graf, J.D. Gradual reduction of PV generator yield due to pollution. In Proceedings of the 2nd World Conference on Photovoltaic Solar Energy Conversion, Austria, Viena, 6-10 July 1998.

81. US Solar Groups Advance Soiling Analysis To Reduce Seasonal Risks. Available online: http: //newenergyupdate.com/pv-insider/us-solar-groups-advance-soiling-analysis-reduce-seasonal-risks (accessed on 15 June 2020).

82. Siska, P.P.; Hung, I.-K. Correlation between pollen dispersion and forest spatial distribution patterns in the Southeastern United States. In Proceedings of the 5th Southern Forestry and Natural Resources GIS Conference, Asheville, NC, USA, 12-14 June 2006; pp. 159-171.

83. Mejía, F.A.; Kleissl, J. Soiling losses for solar photovoltaic systems in California. Sol. Energy 2013, 95, 357-363. [CrossRef]

84. Ghazi, S.; Sayigh, A.; Ip, K. Dust effect on flat surfaces-A review paper. Renew. Sustain. Energy Rev. 2014, 33, 742-751. [CrossRef] 
85. Shaju, A.; Chacko, R. Soiling of photovoltaic modules-Review. IOP Conf. Ser. Mater. Sci. Eng. 2018, 396. [CrossRef]

86. Smith, M.K.; Wamser, C.C.; James, K.E.; Moody, S.; Sailor, D.J.; Rosenstiel, T.N. Effects of natural and manual cleaning on photovoltaic output. J. Sol. Energy Eng. 2013, 135, 034505. [CrossRef]

87. Becker, H.; Vaaben, W.; Herrmann, W. Reduced output of solar generators due to pollution. In Proceedings of the 14th European Photovoltaic Solar Energy Conference and Exhibition (EU PVSEC 1997), Barcelona, Spain, 30 June-4 July 1997; pp. 251-255.

88. Miller, J.T.A.; Jaya, J.; Vipin, G.; Hoffner, J. Sandia National Laboratories, Technical Memorandum: Impact of Soiling and Pollution on PV Generation Performance. 2009. Available online: https://pdfs.semanticscholar. org/f839/f78ce4b9b2fec0b352595f471e7dbbd98fe0.pdf (accessed on 15 June 2020).

89. Weber, M.; Ulrich, S. PalDat 3.0-second revision of the database, including a free online publication tool. Grana 2017, 56, 257-262. [CrossRef]

90. Kimber, A.; Mitchell, L.; Nogradi, S.; Wenger, H. The effect of soiling on large grid-connected photovoltaic systems in California and the Southwest Region of the United States. In Proceedings of the Conference Record of the 2006 IEEE 4th World Conference on Photovoltaic Energy Conversion, WCPEC-4, Waikoloa, HI, USA, 7-12 May 2006; Volume 2, pp. 2391-2395.

91. International Energy Agency. Reliability Study of Grid Connected PV Systems Field Experience and Recommended Design Practice; Report IEA-PVPS T7-08:2000; International Energy Agency: Paris, France, March 2002.

92. National Renewable Energy Laboratory (NREL). Best Practices in Photovoltaic System Operations and Maintenance, 2nd ed.; Technical Report NREL/TP-7A40-67553; National Renewable Energy Laboratory (NREL) lokacija: Golden, CO, USA, 2016.

93. Sapiña, M.; Jiménez-Relinque, E.; Nevshupa, R.; Roman, E.; Castellote, M. Degradation of pollen on nanofunctionalized photocatalytic materials. J. Chem. Technol. Biotechnol. 2017, 92, 210-216. [CrossRef]

94. Pett, C.; Wu, G.; Hudson, W.; Chien, C.-H.; Wu, C.Y.; Guo, B.; Chesnutt, J.; Scheffe, J. Improving Electrodynamic Dust Shield Efficiency for Solar Energy Applications. Available online: https://ufdc.ufl.edu/AA00062790/00053 (accessed on 15 June 2020).

95. Al-Hasan, A.Y. A new correlation for direct beam solar radiation received by photovoltaic panel with sand dust accumulated on its surface. Sol. Energy 1998, 63, 323-333. [CrossRef]

96. Elminir, H.K.; Ghitas, A.E.; Hamid, R.H.; El-Hussainy, F.; Beheary, M.M.; Abdel-Moneim, K.M. Effect of dust on the transparent cover of solar collectors. Energy Convers. Manag. 2006, 47, 3192-3203. [CrossRef]

97. Qasem, H.; Betts, T.R.; Müllejans, H.; AlBusairi, H.; Gottschalg, R. Dust-induced shading on photovoltaic modules. Prog. Photovolt Res. Appl. 2014, 22, 218-226. [CrossRef]

98. El-Shobokshy, M.S.; Hussein, F.M. Effect of dust with different physical properties on the performance of photovoltaic cells. Sol. Energy 1993, 51, 505-511. [CrossRef]

99. Kaldellis, J.K.; Fragos, P.; Kapsali, M. Systematic experimental study of the pollution deposition impact on the energy yield of photovoltaic installations. Renew. Energy 2011, 36, 2717-2724. [CrossRef]

100. Red PALINOCAM (Airborne Pollen Monitoring Network of Madrid). Available online: http://www. comunidad.madrid/servicios/salud/polen (accessed on 15 June 2020).

101. Gutiérrez, M.; Sabariego, S.; Cervigón, P. Calendario polínico de Madrid (Ciudad Universitaria). Periodo 1994. Lazaroa 2006, 27, 2-127.

102. International Electrotechnical Commission (IEC). Photovoltaic System Performance—Part 1: Monitoring; International Standard IEC 61724-1; International Electrotechnical Commission: Geneva, Switzerland, 2017; p. 118.

103. Martín-Chivelet, N.; Polo, J.; Alonso, M.; Sanz, C.; Batlles, F.J.; López, G.; Alonso-Montesinos, J.; Bosch, J.L.; Barbero, J. Characterization and modeling of the soiling effect on the PV generation under urban Mediterranean conditions. In Proceedings of the 36th European Photovoltaic Solar Energy Conference and Exhibition (EU PVSEC 2019), Marseille, France, 9-13 September 2019; pp. 1622-1624.

104. International Energy Agency. Photovoltaic Module Energy Yield Measurements: Existing Approaches and Best Practice; Report IEA-PVPS T13-11:2018; International Energy Agency: Paris, France, 2018.

105. International Electrotechnical Commission. Photovoltaic Devices-Part 3: Measurement Principles for Terrestrial Photovoltaic (PV) Solar Devices With Reference Spectral Irradiance Data 2019; International Standard IEC 60904-3; International Electrotechnical Commission: Geneva, Switzerland, 2019; p. 110. 
106. D'amato, G.; Vitale, C.; Sanduzzi, A.; Molino, A.; Vatrella, A.; D'amato, M. Allergenic pollen and pollen allergy in Europe. Allergy Allerg. Immunother. New Mech. Strateg. 2017, 261-280. [CrossRef]

107. Darwish, Z.A.; Kazem, H.A.; Sopian, K.; Al-Goul, M.A.; Alawadhi, H. Effect of dust pollutant type on photovoltaic performance. Renew. Sustain. Energy Rev. 2015, 41, 735-744. [CrossRef]

108. Southworth, D. Ultraviolet absorption spectra of pollen and spore walls. Grana Palynol. 1969, 9, 5-15. [CrossRef]

109. Fraser, W.T.; Lomax, B.H.; Jardine, P.E.; Gosling, W.D.; Sephton, M.A. Pollen and spores as a passive monitor of ultraviolet radiation. Front. Ecol. Evol. 2014, 2, 10-12. [CrossRef]

110. Gracia, A.M.; Huld, T.; Vourlioti, P.; Müller, R.; Norton, M. Application of satellite-based spectrally-resolved solar radiation data to PV performance studies. Energies 2015, 8, 3455-3488. [CrossRef]

111. Al-Hasan, A.Y.; Ghoneim, A.A. A new correlation between photovoltaic panel's efficiency and amount of sand dust accumulated on their surface. Int. J. Sustain. Energy 2005, 24, 187-197. [CrossRef]

112. Gholami, A.; Saboonchi, A.; Alemrajabi, A.A. Experimental study of factors affecting dust accumulation and their effects on the transmission coefficient of glass for solar applications. Renew. Energy 2017, 112, 466-473. [CrossRef]

113. Bunderson, L.D.; Levetin, E. Hygroscopic weight gain of pollen grains from Juniperus species. Int. J. Biometeorol. 2015, 59, 533-540. [CrossRef]

114. Sabban, L.; van Hout, R. Measurements of pollen grain dispersal in still air and stationary, near homogeneous, isotropic turbulence. J. Aerosol Sci. 2011, 42, 867-882. [CrossRef]

(C) 2020 by the authors. Licensee MDPI, Basel, Switzerland. This article is an open access article distributed under the terms and conditions of the Creative Commons Attribution (CC BY) license (http://creativecommons.org/licenses/by/4.0/). 